\title{
The Role of Hesperidin on Healing an Incised Wound in an Experimentally Induced Diabetic Adult Male Albino Rats. Histological and Immunohistochemical Study
}

\author{
Rania Ibrahim Yassien and Dalia El-sayed El-Ghazouly
}

Department of Histology, Faculty of Medicine, Menoufia University, Shebin el Kom, Egypt

\begin{abstract}
Background: Skin ulcers and poor healing are serious problems in diabetic patients. Products of citrus herbal are promising in new studies. Many benefits of hesperidin especially for cutaneous functions including skin healing have been demonstrated. Aim of the Study: The aim of this work was to evaluate the possible healing effect of hesperidin on diabetic skin injury in adult male albino rats.

Materials and Methods: Forty adult male albino rats were randomly divided into four equal groups (10 rats, each). Group I: the control; group II: hesperidin; group III: untreated diabetic rats; and group IV, diabetic rats treated with hesperidin. Skin specimens were obtained and processed for histological study using Hematoxylin and Eosin (H \& E), Mallory trichrome (M.T) and immunohistochemical study using vascular endothelial growth factor (VEGF) Electron microscopic examination was done. Morphometric measurements of epidermal thickness and area percentage of collagen fibers were carried out followed by statistical analysis.

Results: The untreated diabetic group showed incomplete closure and scab covering proliferating epidermis. Another area of self- healed malformed skin revealed reepithelization with increased thickness of epidermis significantly. Epidermal cells showed loss of polarity and in between hyaline material. The underlying dermis revealed a significantly increased disorganized collagen fibers and massive inflammatory cells infiltration. Also, moderate VEGF immunoexpression was observed. Diabetic skin treated with hesperidin revealed complete closure of the wounds with thin apparently normal epidermis. The underlying dermis revealed normal amount of well-organized collagen fibers with few inflammatory cells infiltration and spaces between collagen fibers. Strong positive VEGF immunoexpression was observed reflecting enhanced angiogenesis.

Conclusion: Diabetic skin injuries are healing badly in relatively prolonged time. Hesperidin can be used as an adjunctive or alternative agent in diabetic wound giving good cosmetic results.
\end{abstract}

Received: 21 March 2020, Accepted: 31 May 2020

Key Words: Diabetic hesperidin, skin wound, VEGF.

Corresponding Author: Rania Ibrahim Yassien, PhD, Department of Histology, Faculty of Medicine, Menoufia University, Shebin el Kom, Menoufia, Egypt, Tel.: +20 1028073793, E-mail: raniayassien@yahoo.com

ISSN: 1110-0559, Vol. 44, No.1

\section{INTRODUCTION}

Diabetes mellitus is a serious metabolic disease that influences more than 340 million persons and nearly $20 \%$ of them suffer from diabetic skin wounds all over the world ${ }^{[1]}$. Skin loss and poor wound healing are serious problems in diabetic patients ${ }^{[2]}$ and form a considerable load to health care systems worldwide ${ }^{[3]}$.

Wound healing is a complex process characterized by a series of separate and overlapped steps such as clot formation, inflammation, proliferation and remodeling phases ${ }^{[2]}$. After injury, inflammatory cells are inducted and produce various growth factors, cytokines and chemokines, which in turn stimulate local habitant cells (keratinocytes, fibroblasts, and endothelial cells) to migrate, proliferate, and make a spot of vascularized connective tissue thereby closing the wound. Although keratinocytes are the main cells responsible for wound re-epithelialization, dermal fibroblasts supply the matrix for keratinocytes to migrate over and endothelial cells produce new blood vessels ${ }^{[4]}$. However, increased pro-inflammatory cytokines such as tumor necrosis factor (TNF) and interleukin (IL-1) extend the phase of inflammation leading to chronic injuries or formation of hypertrophic scar ${ }^{[5]}$.

Diabetic wounds usually recover slowly and return frequently, not only resulting in a rise in the medical care cost but also decreasing the life quality of diabetic patients seriously ${ }^{[6]}$.

The worldwide rise in the prevalence of DM boosts the search for solutions to prevent it as well as counter the development and progression of its complications, such as ulcers and delayed wound healing ${ }^{[7]}$.

Hesperidin (hesperetin-7-rhamnoglucoside) is a bioflavonoid found in citrus fruits such as tangerine, orange, and lemon as well as in plant extracts as tea and olive oil. The highest concentrations of hesperidin are present in citrus fruit peels ${ }^{[8]}$. Hesperidin has been stated to be antibacterial, 
antiviral, anti-inflammatory and analgesic in many studies ${ }^{[9]}$. In addition to its antidiabetic effects, new researches have detected many benefits of hesperidin for skin, as wound healing, Ultra-Violet protection, anticancerous and skin lightening. Moreover, hesperidin improves epidermal homeostasis in normal skin whether young or aged ${ }^{[10]}$.

Since the existing standard treatments for the diabetic wounds in clinics have not reached the favorable results, we insistently need more efficient therapeutic approaches to accelerate diabetic wound healing in a good cosmetic way. Therefore, the aim of this study was to evaluate the possible healing effect of hesperidin on diabetic skin wound in adult male albino rats using histological and immunohistochemical techniques.

\section{MATERIALS AND METHODS}

\section{Animals}

This study was carried out on 40 adult male albino rats weighing 200-250 g.

Animals were housed in clean properly ventilated cages, fed on a standard laboratory diet, and maintained on a12-h light/dark photoperiod in the animal house of the Faculty of Medicine, Menoufia University, Shebin el Kom, Menoufia, Egypt. This experiment was done according to the Animal Care and Ethical Committee Guidelines of the Faculty of Medicine, Menoufia University.

\section{Drugs}

Hesperidin and streptozotocin powder forms were purchased from Sigma Chemicals Co., St. Louis, MO, USA. They stored at $2-4{ }^{\circ} \mathrm{C}$.

Rats were randomly divided into four equal groups

- Group I (Control group): included 10 rats which then subdivided equally into:

- group Ia (5 rats): received only food and water.

- $\quad$ group $\mathrm{Ib}$ (5 rats): received an equal volume of vehicle i.p. (0.05 $\mathrm{M}$ citrate buffer).

- Group II (Hesperidin): included 10 rats that received aqueous suspension of hesperidin $(50 \mathrm{mg} / \mathrm{kg})$ orally for 30 days $^{[11]}$.

- Group III (Untreated diabetic): included 10 rats with induced diabetes followed by incised wound on the same day of confirmation of diabetes, then left untreated for 30 days.

- Group IV (Diabetic treated with hesperidin): included 10 diabetic rats that underwent the same procedure as group III. But after the wound incision, hesperidin was applied for the same dose and duration as group II.

\section{Induction of diabetes}

Induced diabetes in groups III and IV was done by streptozotocin (STZ) powder. Rats turned diabetic by a single intra-peritoneal (i.p.) injection of STZ ( $40 \mathrm{mg} / \mathrm{kg}$ body weight) dissolved in $1 \mathrm{ml}$ of $0.05 \mathrm{M}$ citrate buffer PH 4.5 ${ }^{[12]}$.

Rats injected by streptozotocin were allowed to drink $10 \%$ glucose solution 24 hours following injection to overcome drug induced hypoglycemia ${ }^{[13]}$. Rats were screened for blood glucose levels after seven days following STZ injection. The blood samples were collected from the tail vein and blood glucose levels were measured using OneTouch Ultra Easy blood glucose meter (Johnson \& Johnson, New Brunswick, NJ, USA). Rats with a blood glucose level over $16.7 \mathrm{mmol} / \mathrm{L}$ were considered as diabetes-induced rats ${ }^{[14]}$.

\section{The wound model}

Rats of groups III and IV underwent general anesthesia using pentobarbital $(45 \mathrm{mg} / \mathrm{kg}$ body weight) intraperitoneally ${ }^{[15]}$ Then, the dorsal hair was shaved and $1 \mathrm{~cm}$ diameter full thickness skin excision was generated in the mid back region using disposable scalpel. The wounds were then cleaned with povidone-iodine.

All rats were sacrificed $24 \mathrm{~h}$ after the last dose of hesperidin. Animals were anesthetized via inhalation ether $(2 \mathrm{ml})$ for approximately $2 \mathrm{~min}$ in a transparent acrylic jar ${ }^{[15]}$. Skin specimens were dissected out and perfused with cold saline, then prepared for light and electron microscopic examination.

\section{A- Light microscope study}

Skin specimens were fixed in $10 \%$ formalin and processed in the usual way to obtain the ordinary paraffin blocks. Sections of $4 \mu \mathrm{m}$ thick were cut and subjected to the following studies.

1. Histological examination: using Hematoxylin and eosin (H \& E) stain and Mallory trichrome (M.T.) for collagen detection ${ }^{[16]}$

2. Immunohistochemical examination: Anti-vascular endothelial growth factor (VEGF) staining was performed. Endogenous peroxidase was inactivated by incubation in 3\% hydrogen peroxide. Slides were incubated overnight at $4{ }^{\circ} \mathrm{C}$ with rabbit antiVEGF antibody (1:500 dilutions) (Pharminagen, Mississauga, Canada). The antibody was diluted in $0.01 \mathrm{~mol} / \mathrm{L}$ phosphate buffered saline (PBS) $\mathrm{pH}$ 7.5 , containing $20 \mathrm{~g} / \mathrm{L}$ bovine serum albumin and $1 \mathrm{~g} / \mathrm{L}$ sodium azide (100 L/tissue section). Goat anti-rabbit $\operatorname{IgG}$ (1:100 dilution) (Vector Laboratories, Burlingame, CA) was used as secondary antibody. Tissue sections were counter-stained with hematoxylin ${ }^{[17]}$.

\section{B-Electron microscope study}

Tissue samples from 4 rats were randomly chosen in each group. Small biopsies from the skins of the sacrificed animals were excised rapidly (within $1 \mathrm{~min}$ ) and trimmed into about $1 \times 1 \mathrm{~mm}^{2}$ pieces. Then fixed in $2.5 \%$ buffered glutaraldehyde, processed and then embedded in epoxy resin by routine protocol. Preparation of ultrathin grids was done 
by staining with uranyl acetate and lead citrate and then examined by electron microscope. Grids were examined with the transmission electron microscope (Seo-Russia) in Tanta E.M Center, Faculty of Medicine, Tanta University ${ }^{[18]}$.

\section{C-Histomorphometrical study}

Measurements of epidermis and dermis were done from six different fields from six serial stained sections of all animals of each group. All measurements were taken using the image analyzer (Leica Q $500 \mathrm{MC}$ program, Wentzler, Germany) in the Anatomy Department, Faculty of Medicine, Menoufia University.

1. Total thickness of epidermis in H\&E stained sections

2. Area percentage of collagen fibers in dermis in M.T. stained sections.

\section{Statistical study}

Morphometric data were statistically analyzed using SPSS (Statistical Package for the Social Sciences) program, version 17, (IBM Corporation, Somers, New York, USA). The data was presented as mean \pm SEM (standard error of mean). The mean of each group was compared with that of the others using one-way analysis of variance (ANOVA) then "Turkey" post hoc test. When $P$ value was $<0.05$, results were considered significant ${ }^{[19]}$.

\section{RESULTS}

\section{Light microscopic results}

Histological examination

\section{- Hematoxylin and Eosin staining}

Sections of the skin of the control group (Ia and $\mathrm{Ib}$ ) revealed the normal histological architecture of the skin. The skin consisted of epidermis and dermis with apparent dermoepidermal junction. The epidermis arranged into four layers of keratinocytes which consisted of stratified squamous keratinized epithelium. The stratum basal consisted of low columnar cells with oval nuclei and rested on the basement membrane. The stratum spinosum was next to basal layer which consisted of polyhedral cells with central rounded vesicular nuclei and followed by the spindle shaped cells of stratum granulosum with basophilic keratohyalin granules. Finally, the stratum corneum consisted of several layers of flattened non-nucleated keratinized cells. The dermis consisted of outer papillary layer and inner reticular layer. The outer papillary layer of the dermis showed mainly connective tissue cells, whereas the inner reticular layer of the dermis composed of a denser connective tissue rich in fibers. The dermis contained hair follicles with the associated sebaceous glands (Figures 1,2). Sections of the skin of hisperidin treated group (II) showed a picture similar to the control (Figure 3). The untreated diabetic rats (group III) showed loss parts of skin (epidermis and dermis). The partially lost skin (wound) was covered by irregular scab. Scab formed of blood cells and fibrin to prevent further dehydration of the healing skin underneath and to protect it from infections. The epidermis proliferated forming epidermal tongue between the two edges of the wound. This area showed also disruption of the underlying dermis (Figure 4). The self-healed part of the wound revealed re-epithelization with very thick epidermis and thickened keratin layer. Although the epidermis was completely formed, it was malformed and very thick. There was an apparent increase in the number of epidermal cells (hyperplasia) with hypertrophy of its cells especially stratum granuolosum. Moreover, the cells of stratum granuolosum demonstrated numerous and coarse basophilic keratohyalin granules (Figures 5, 6, 7). The epidermal cells showed loss of polarity (Figures 8,9 ) and surrounding by an eosinophilic hyaline material (Figure 9). Also, some nuclei of the epidermal cells had perinuclear halos which was normal appearance of non-keratinocytes (Figure7). The underlying dermis revealed disorganized collagen fibers with massive inflammatory cells infiltration. Many hair follicles with absence of the associated sebaceous glands were observed in the dermis (Figures 5-8). Hyperplasia and proliferation of some hair follicles cells as a source of stem cells called follicular bulge was noticed in some sections (Figure 5). There were wide spaces (Figures 4,8) and few blood capillaries in the dermis (Figures 4, 8, 10). In group IV, H \& E picture revealed complete closure of the wounds in all sections. There was complete re-epithelization with apparently normal epithelium. The epidermis appeared thin with flattening of the dermo -epidermal junction. The underlying dermis revealed well organized collagen fibers with newly formed blood capillaries reflecting the occurrence of angiogenesis. Also, the dermis had hair follicles and sebaceous glands with few inflammatory cell infiltration and spaces between collagen fibers were still present (Figure 11).

\section{- Mallory's trichrome staining}

M.T. stained sections of the skin from the control and hisperidin treated groups (Groups I and II) revealed collagen fibers as thin interlacing bundles in papillary dermis but those of reticular dermis were coarse wavy (Figures 12,13). The untreated diabetic rats in group III revealed a great amount of collagen fibers in the dermis which appeared more dense, thicker, wavy and disorganized (Figures 14, 15). Moreover, some collagen fibers were seen inside the epidermis surrounded by epidermal cells (Figure 15). Group IV revealed a picture nearly similar to the control group (Figure 16).

\section{Immunohistochemical examination}

\section{Vascular endothelial growth factor (VEGF) staining}

In the control and hesperidin treated groups (Groups I and II), VEGF immunoreactivity was mild positive in the superficial layers of keratinocytes, in the external root sheath of hair follicles and in few cells of the dermis (Figures 17, 18). The untreated diabetic rats in group III revealed moderate positive immunoreactivity for VEGF in keratinocytes and some cells of the dermis (Figures 19, 20) and in external root sheath of hair follicles (Figure 20). While the diabetic rats treated with hesperidin (group IV) revealed very strong positive immunoreactivity in keratinocytes, in external root sheath of hair follicles and many cells of the 
dermis reflecting enhanced angiogenesis (Figure 21).

\section{Electron microscopic results}

Ultrathin sections of the skin of the control and hesperidin treated groups (group Ia \& Ib and II) revealed that it consisted of epidermis and dermis. The epidermis consisted mainly of four different layers of keratinocytes; stratum basal, spinosum, granulosum and corneum. The cells of St. basal were columnar in shape having regular oval euchromatic nuclei with prominent nucleoli, rested on continuous basement membrane and connected with it by hemidesmosomes. Their cytoplasm contained many mitochondria, intermediate keratin filaments and melanosomes (Figures 22, 26). The cells of St. spinosum had euchromatic nuclei and bundles of tonofilaments in the cytoplasm. These cells were connected together by intact desmosomal junctions (Figures 23, 27). The cells of stratum granulosum had oval euchromatic nuclei and filled with variable sized electron dense keratohyalin granules. The St. corneum formed of regular lamellae of keratin. The stratum corneum-stratum granulosum interface showed multiple lipid lamellae (Figures 24, 28). The dermis had spindle-shaped fibroblasts containing euchromatic elongated nuclei with peripheral heterochromatin. In addition, regularly arranged collagen bundles were seen in the dermis (Figures 25, 29). Ultrathin sections of the untreated diabetic skin of group III showed the self-healed part of the skin with its epidermal and dermal layers. The epidermis appeared thickened formed of four layers. The St. basal demonstrated basal columnar cells resting on a discontinuous basement membrane. These cells had irregular nuclei with abundant keratin filaments in the cytoplasm. Also, their cytoplasm contained electron-lucent cytoplasmic vacuoles most probably swollen mitochondria with destroyed cristae. Cells appeared with dilatation of the intercellular spaces and loss of cellular junctions this allowed the cells to migrate to cover edges of the wound (Figure 30 ). The cells of stratum spinosum showed different degrees of degeneration. Some cells appeared with hyperchromatic shrunken nuclei surrounded by electron pale area. These cells revealed many tonofilament bundles, some of filaments appeared fragmented and condensed. Moreover, irregular desmosomal junctions between the cells with widening of intercellular space were noticed (Figure 31). The cells of the stratum granulosum appeared with abundant and enlarged keratohyalin granules (hyper-granulosis). The nuclei of these cells appeared hyperchromatic with numerous indentations. The stratum corneum appeared thickened and disrupted with multiple lamellae of keratin (Figure 32). The underlying papillary dermis contained excessive amount of disorganized collagen fibers. The dermis showed excessive inflammatory cells as macrophage and fibroblasts (Figures 33, 34). Some macrophages had irregular surface with few protrusions and indentations (pseudopodia). It could be inflammatory monocyte-derived macrophage which is polarized toward macrophage 1 (M1). They could also undergo in situ phenotype conversion to become tissue-resident macrophage 2 in its attempt of healing. Their heterochromatic nuclei were kidney shape. Their cytoplasm contained numerous lysosomes (Figure 33). Numerous active fibroblasts were located in the dermis. They appeared with cytoplasmic processes containing dilated cisternae of rough endoplasmic reticulum (Figure 34). Also, the dermis of group III revealed myofibroblast cells with characteristic features. These cells showed intracytoplasmic microfilaments peripherally which arranged parallel to the axis of the cell, many indentations and deep folds of the nucleus that give indirect evidence of contraction (Figure 34). Ultrathin sections of the diabetic skin treated with hesperidin showed the newly formed epidermis covering the wound area. The epidermal cells had ultrastructural features nearly similar to those of the control group but small intracellular vacuolations were still seen (Figures 35-37). The underlying dermis showed regularly arranged collagen fibers, fibroblasts with some dilated rough endoplasmic reticulum and myofibroblasts infiltration still present (Figures 38, 39).

\section{Morphometric and Statistical Results}

\section{1- Epidermal thickness}

The mean epidermal thickness of rats of group II showed non-significant difference $(P>0.05)$ when compared with that of the control group. The untreated diabetic rats of group III showed a highly significant increase $(P<0.001)$ in the mean epidermal thickness of self-healed area when compared with the control group. However, the diabetic rats treated with hesperidin of group IV showed a significant decrease $(P<0.05)$ in the epidermal thickness when compared with the control (Table 1, Histogram 1).

\section{2- Percentage area of collagen fibers}

The mean percentage area of collagen fibers of rats in group II showed non-significant difference $(P>0.05)$ when compared with that of the control group. The untreated diabetic rats of group III showed a highly significant increase $(P<0.001)$ in the percentage area of collagen fibers when compared with the control group. However, hesperidin treated diabetic rats of group IV showed a non-significant difference $(P>0.05)$ in the percentage area of collagen fibers when compared with the control (Table 1, Histogram 2).

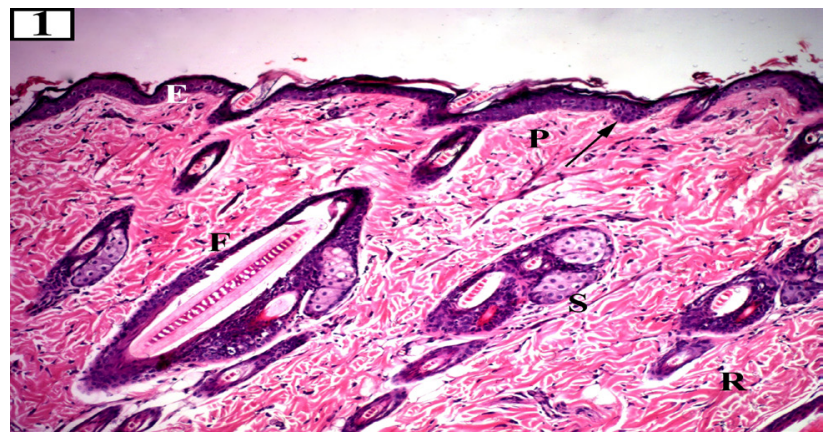

Fig. 1: A photomicrograph of a section in a rat skin of the control group (group I) showing the epidermis (E) and the underlying dermis with its papillary $(\mathrm{P})$, reticular layers $(\mathrm{R})$ and apparent dermo-epidermal junction (arrow). Note : the hair follicles (F) and accompanying sebaceous glands (S). H\&E, $\times 100$. 


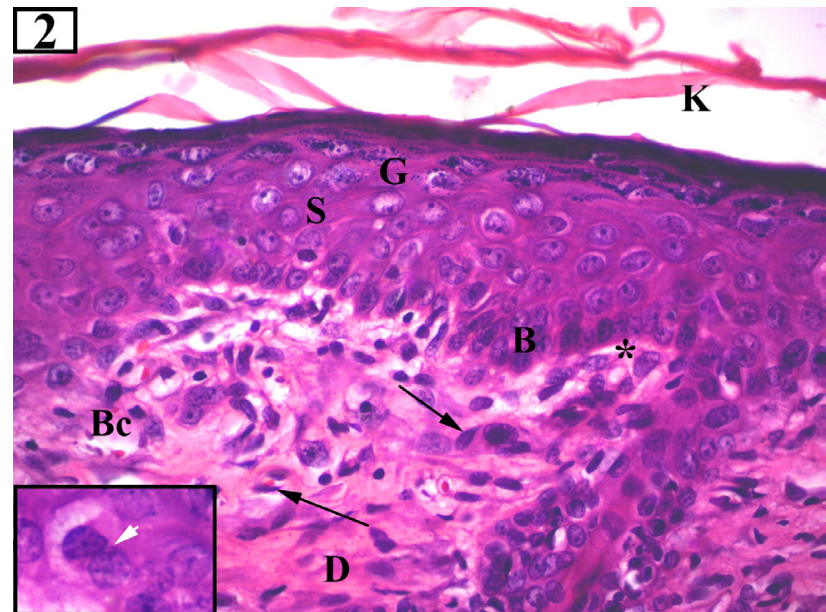

Fig. 2: A photomicrograph of a section in a rat skin of the control group (group I) showing the layers of the epidermis: The stratum basal (B) with low columnar basal cells and oval nuclei resting on basal lamina $(*)$, the stratum spinosum (S) with polyhedral cells and rounded central vesicular nuclei, the stratum granulosum $(\mathrm{G})$ with spindle shaped cells containing deeply basophilic keratohyalin granules and the stratum corneum $(\mathrm{K})$ formed of many layers of flattened non-nucleated keratinized cells. The dermis (D) contains many connective tissue cells and fibers. The cells have spindle shaped nuclei (arrows). Note: blood capillaries $(\mathrm{Bc})$ in the dermis. The inset shows mitosis and two new cells in the stratum basal (short arrow). H\&E, $\times 400$, inset $\times 1000$.

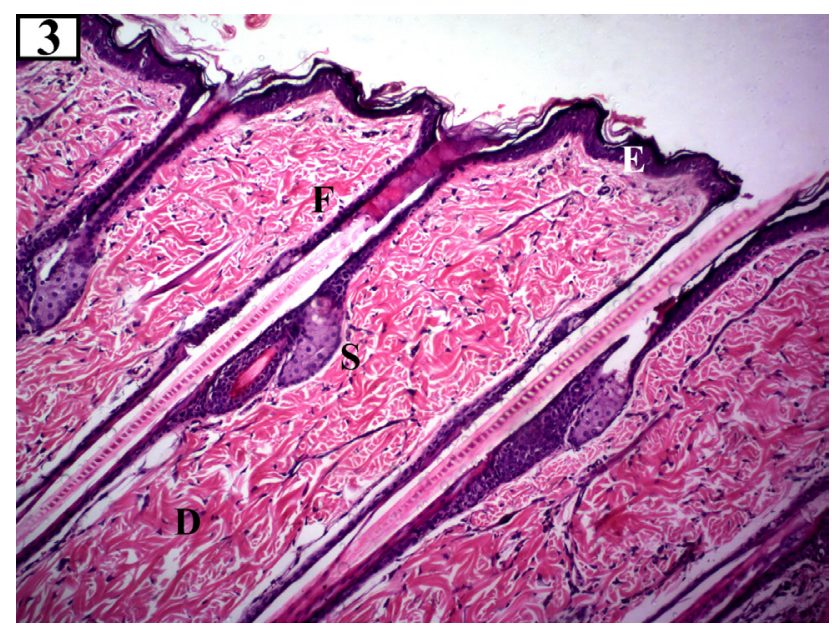

Fig. 3: A photomicrograph of a section in a rat skin of the hesperidin treated group (group II) showing a picture similar to the control group with normal appearance of the epidermis (E) and underlying dermis (D). Note: the hair follicles (F) and accompanying sebaceous glands (S). H\&E, $\times 100$

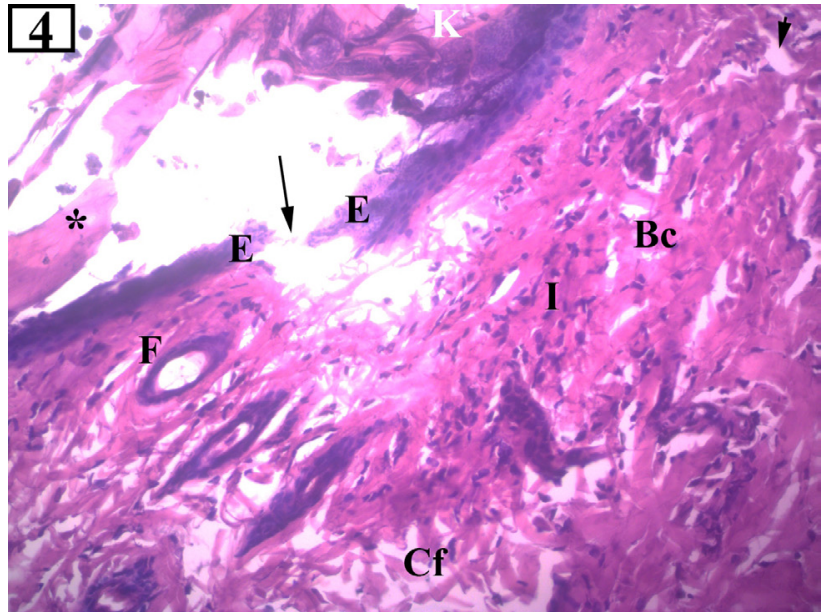

Fig. 4: A photomicrograph of a section in untreated diabetic skin wound of group III showing lost part of epidermis (arrow) covered by irregular scab (*). The creeping epidermis (E) proliferates forming epidermal tongue between the two edges of the wound covered by irregular keratin (K). There is diffuse and massive infiltration with inflammatory cells (I) and few blood capillaries (Bc) in the dermis. Reduced thickness of hair follicle layers $(\mathrm{F})$ is observed. Notice: disorganized collagen fibers in the dermis (Cf) and wide space in between (short arrow) are seen. H \&E X 200

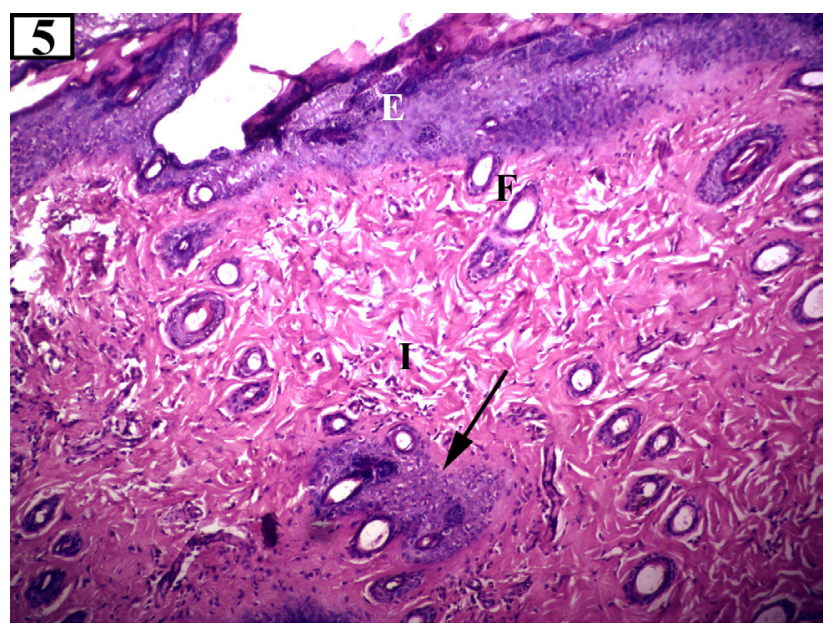

Fig. 5: A photomicrograph of a section in untreated diabetic skin wound of group III showing a part of the wound area with re-epithelization. The epidermis (E) appears continuous and very thick. There is marked inflammatory cell infiltration (I) in the dermis. Many hair follicles (F) with absence of associated sebaceous glands are observed. Notice: increased cellular proliferation (hyperplasia) of some hair follicles as follicular bulge (arrow). H \&E X 100

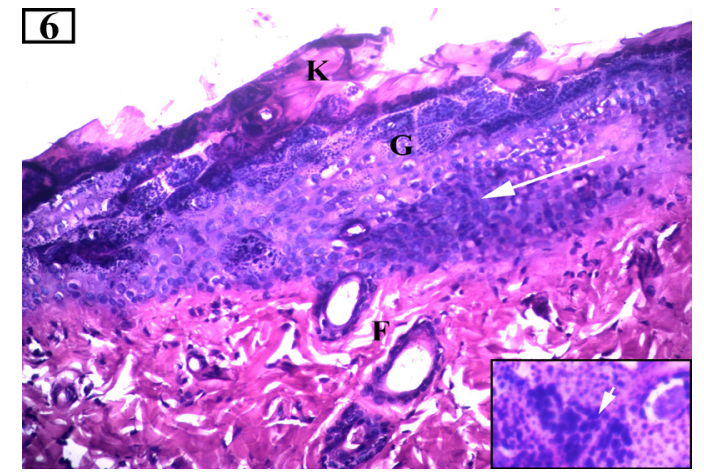

Fig. 6: A higher magnification of the previous section showing increased cellular proliferation of epidermis (arrow) with thick keratin layer (K). There is apparent hypertrophy of the cells of stratum granuolosum $(\mathrm{G})$. Hair follicles (F) with absence of associated sebaceous glands are seen. The inset shows numerous and coarse basophilic keratohyalin granules of cells of stratum granuolosum (short arrow). H \&E X 400, inset $\times 1000$ 


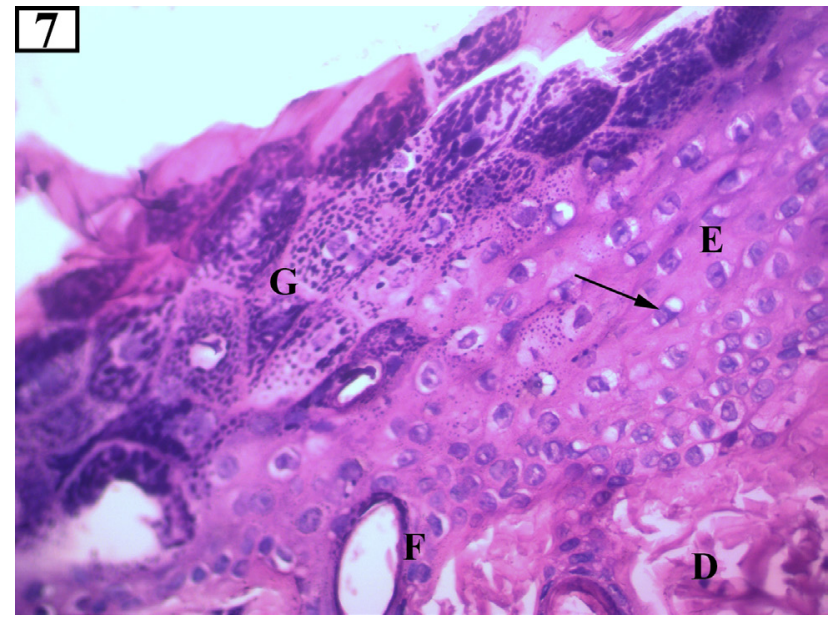

Fig. 7: A photomicrograph of a section in a diabetic skin wound of group III showing continuous epidermis. The epidermis (E) appears very thick. Some cells (non keratinocytes) appear with perinuclear halos (arrow). The cells of stratum granuolosum $(\mathrm{G})$ with its granules and irregular dermis (D) contained degenerated hair follicles (F) are seen. H \& E X 400

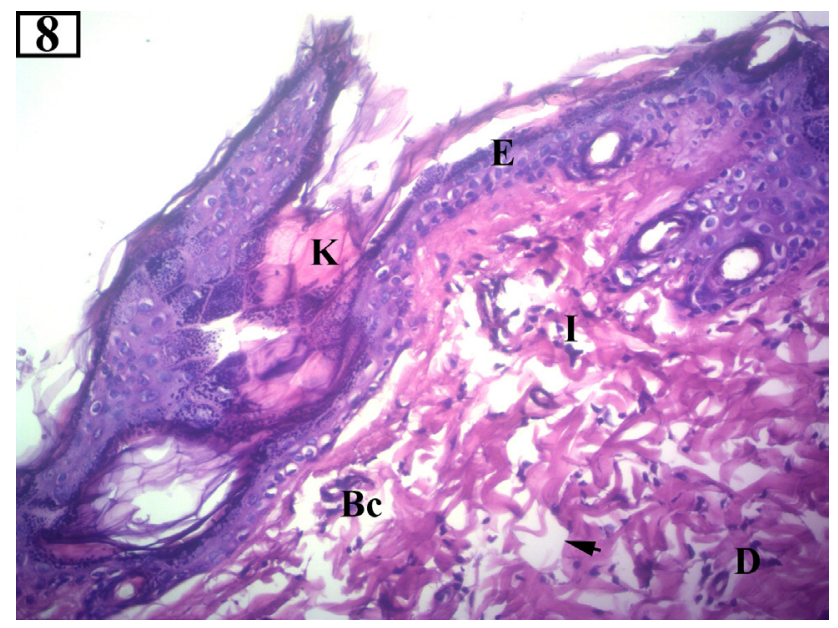

Fig. 8: A photomicrograph of a section in a diabetic skin wound of group III showing a part of the self-healed epidermis (E) appearing malformed. The epidermis has an abnormal shape with the epidermal cells showing loss of polarity and invasion of keratin $(\mathrm{K})$ between epidermal cells. Inflammatory cell infiltration (I) is seen in the underlying dermis (D) Wide spaces (short arrow) and few blood capillaries (Bc) are also seen in dermis. H \&E X 200

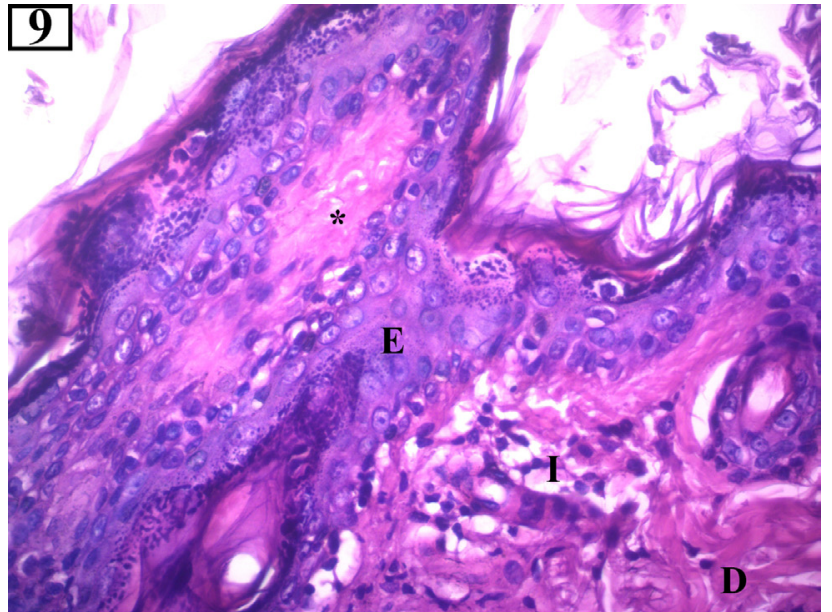

Fig. 9: A photomicrograph of a section in a diabetic skin wound of group III showing a part of the healed epidermis (E) appearing malformed. The epidermis has an abnormal shape with the epidermal cells showing loss of polarity and surrounded by an eosinophilic hyaline material $(*)$. Inflammatory cell infiltration (I) is seen in the underlying dermis ('D). $\mathrm{H}$ \&E X 400

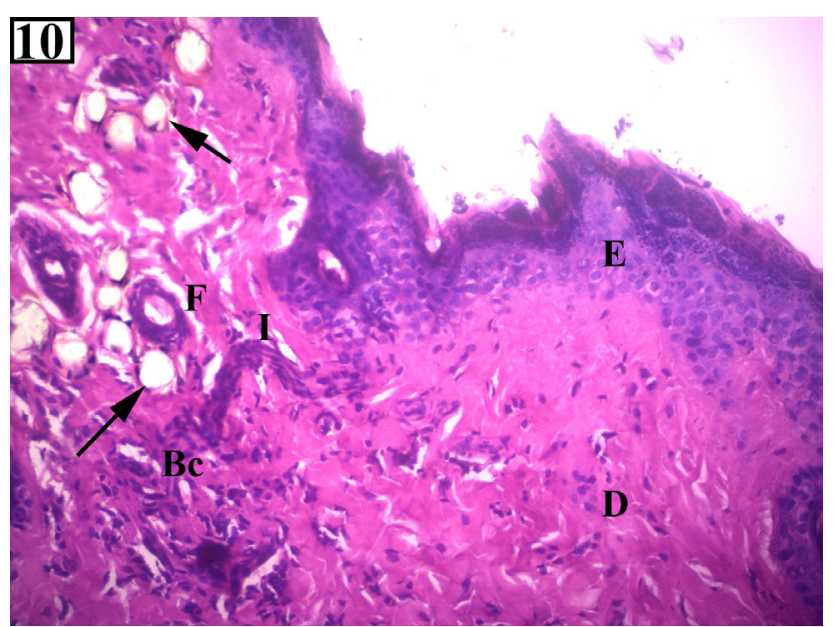

Fig. 10: A photomicrograph of a section in a diabetic skin wound of group III showing an area of the healed wound with thick abnormal epidermis (E). The underlying dermis (D) appears dense with massive infiltration with inflammatory cells (I) appearing in patches with few capillaries (Bc) Some fat cells are observed in the dermis (arrows) around hair follicles (F). H \&E X 200

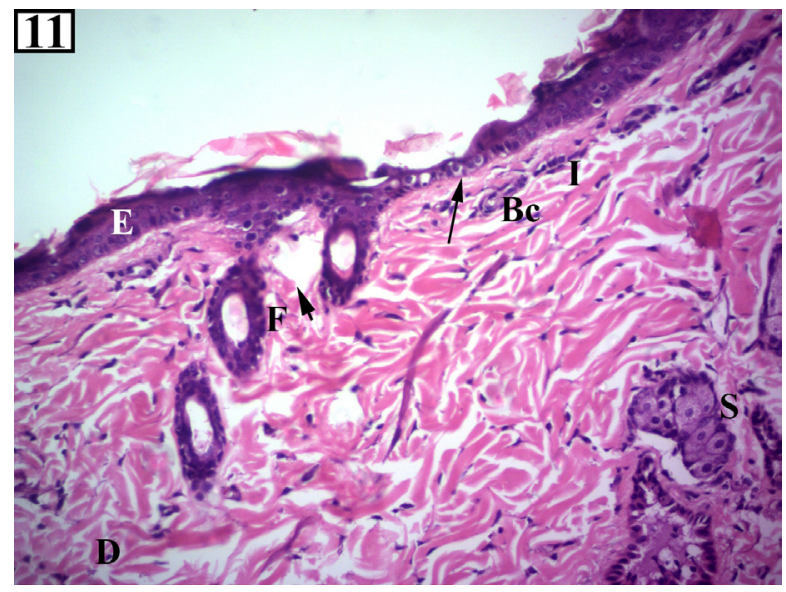

Fig. 11: Photomicrograph of a section in a diabetic skin wound treated with hesperidin of group IV showing that the wound is completely covered by a thin epidermis (E ) with flattening of the dermo-epidermal junction (arrow). In the dermis(D) newly formed blood capillaries (Bc), hair follicles (F) and sebaceous glands (S) are observed. Note: little inflammatory cell infiltration (I) and few spaces ( short arrow) are still seen. H \&E X 200 


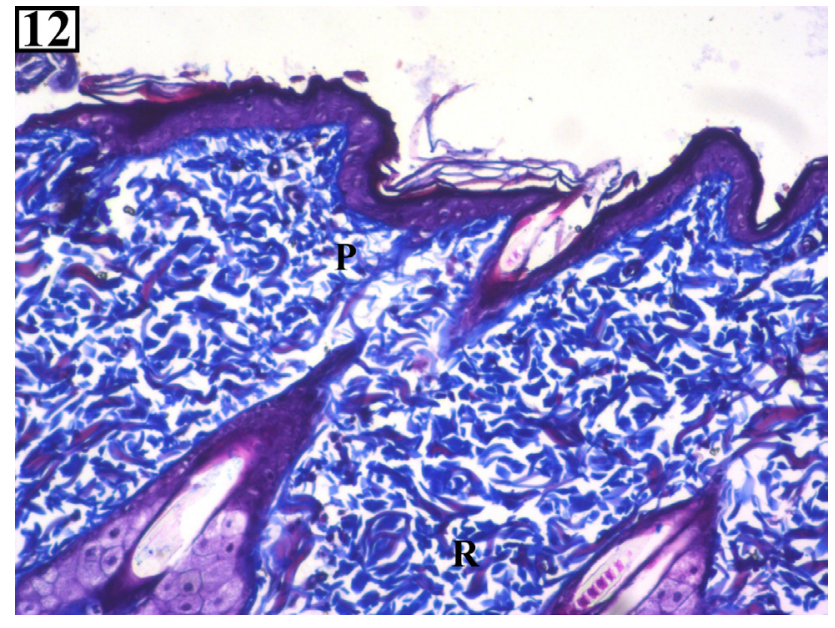

Fig. 12: A photomicrograph of a section in a rat skin of the control group (group I) showing the collagen fibers in the papillary (P) dermis appear as thin interlacing bundles whereas those in the reticular dermis (R) appear as coarse, wavy bundles. [Mallory's trichrome X 200]

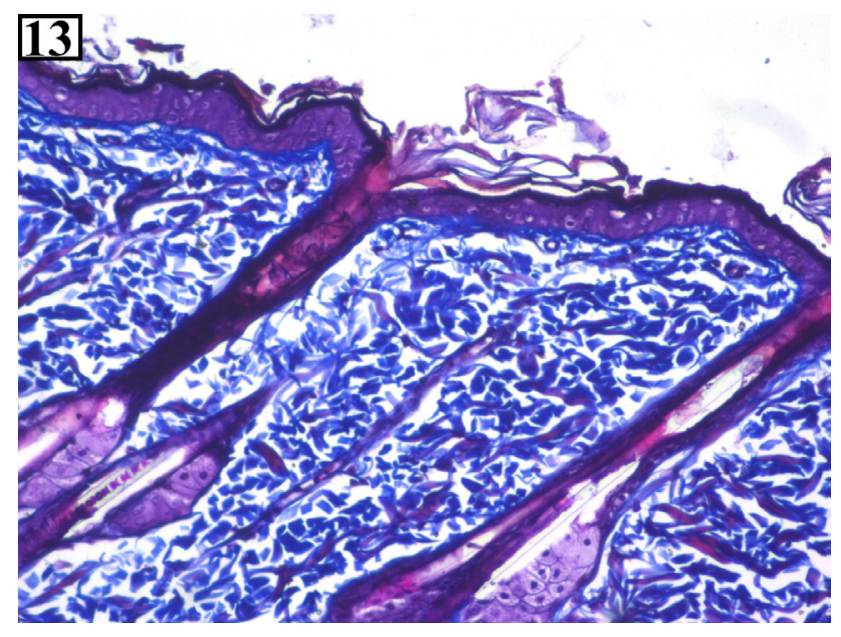

Fig. 13: A photomicrograph of a section in a rat skin of the hesperidin treated group (group II) showing the collagen fiber content of dermis which appear similar to those of the control group. [ Mallory's trichrome X 200]

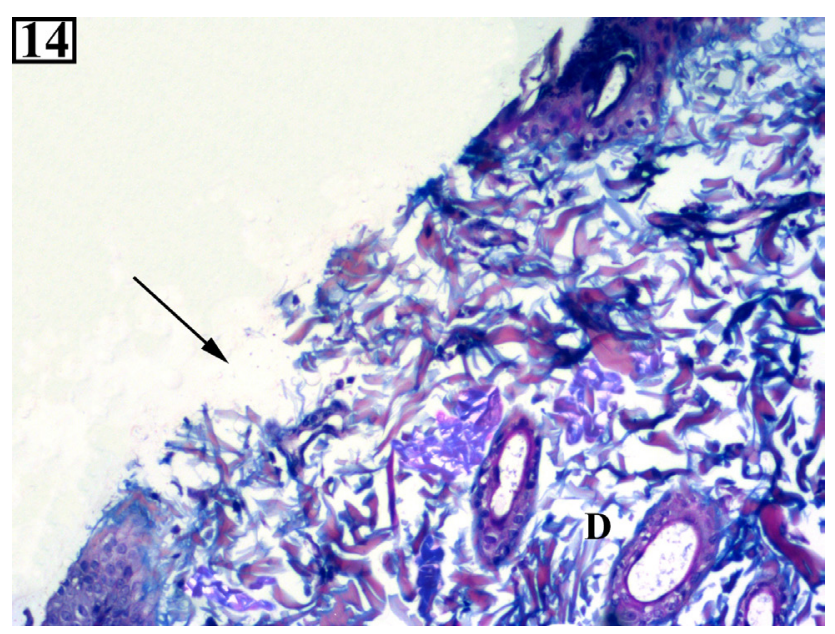

Fig. 14: A photomicrograph of a section in a diabetic skin wound of group III showing great amount of collagen fibers in the dermis (D) which appear more dense, thicker, wavy and disorganized when compared with those of the control group. Epidermal loss is seen (arrow). [ Mallory's trichrome X 200]

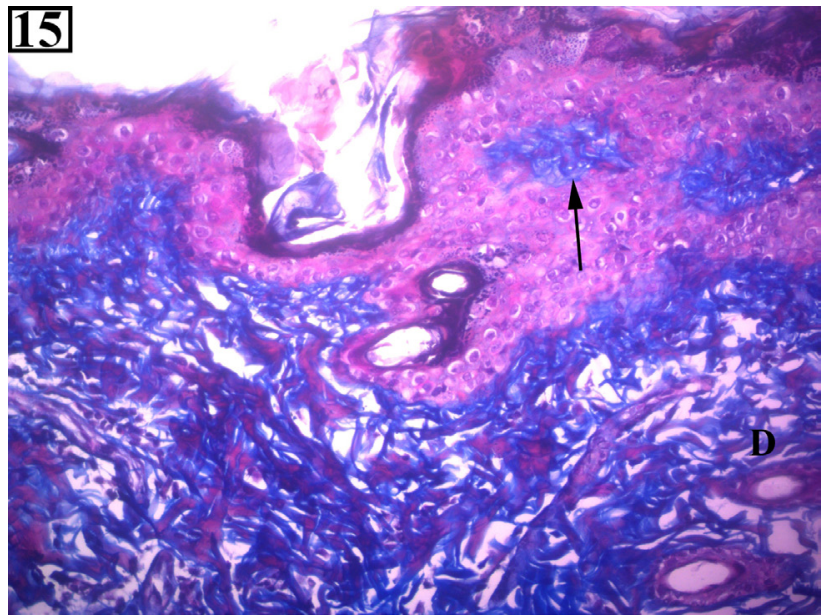

Fig. 15: A photomicrograph of a section in a diabetic skin wound of group III showing great amount of collagen fibers in the dermis (D) which appear more dense, thicker, wavy and disorganized when compared with those of the control group. Some collagen fibers (arrow) are seen inside the epidermis surrounded by epidermal cells. [Mallory's trichrome X 200]

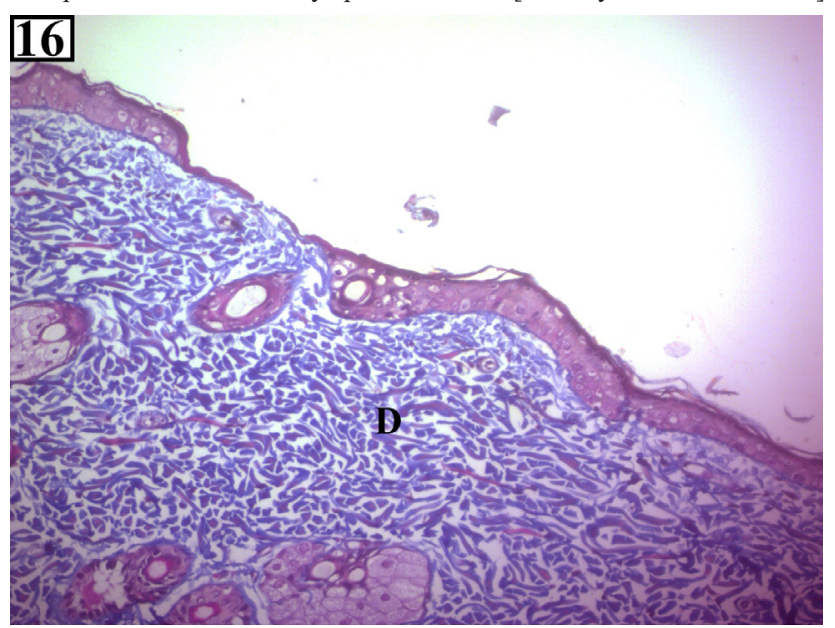

Fig. 16: A photomicrograph of a section in a diabetic skin wound treated with hesperidin (group IV) showing the collagen fibers of the dermis (D) which appear nearly similar to those of the control group. [ Mallory's trichrome X 200 ]

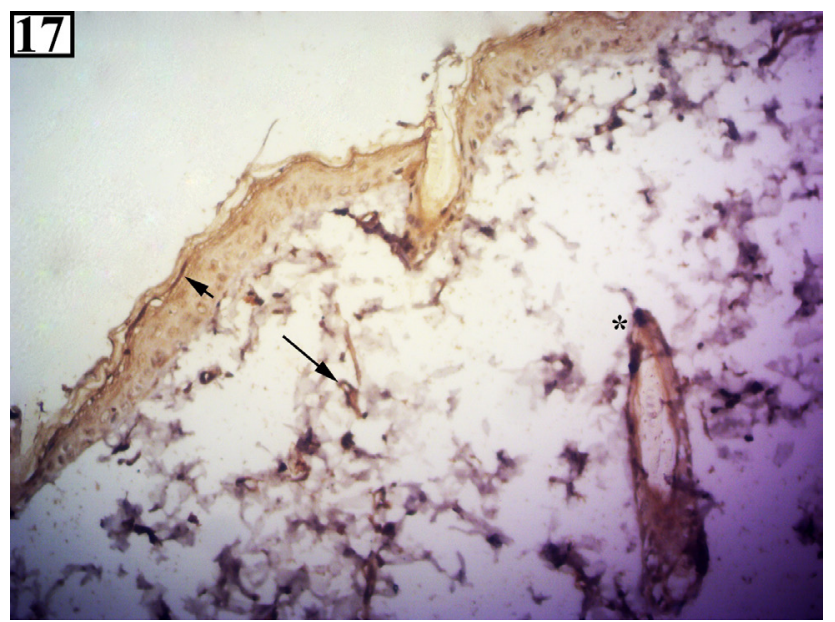

Fig. 17: A photomicrograph of a section in a rat skin of the control group (I) showing mild positive cytoplasmic immunoreactivity for vascular endothelial growth factor (VEGF) in the superficial layers of keratinocytes of epidermis (short arrow), in external root sheath of the hair follicles $\left(^{*}\right)$ and in some cells of the dermis (arrow). (VEGF $\times 200)$ 


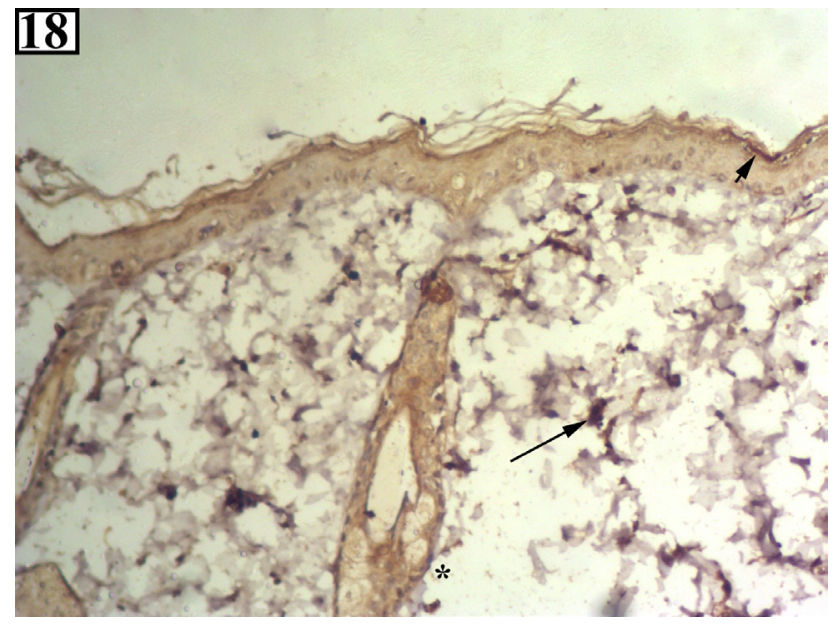

Fig. 18: A photomicrograph of a section in a rat skin of the hesperidin treated group (group II) showing mild positive cytoplasmic immunoreactivity for VEGF in the superficial layers of keratinocytes of epidermis (short arrow), in external root of the sheath of hair follicles $(*)$ and in some cells of the dermis (arrow). (VEGF $\times 200$ )

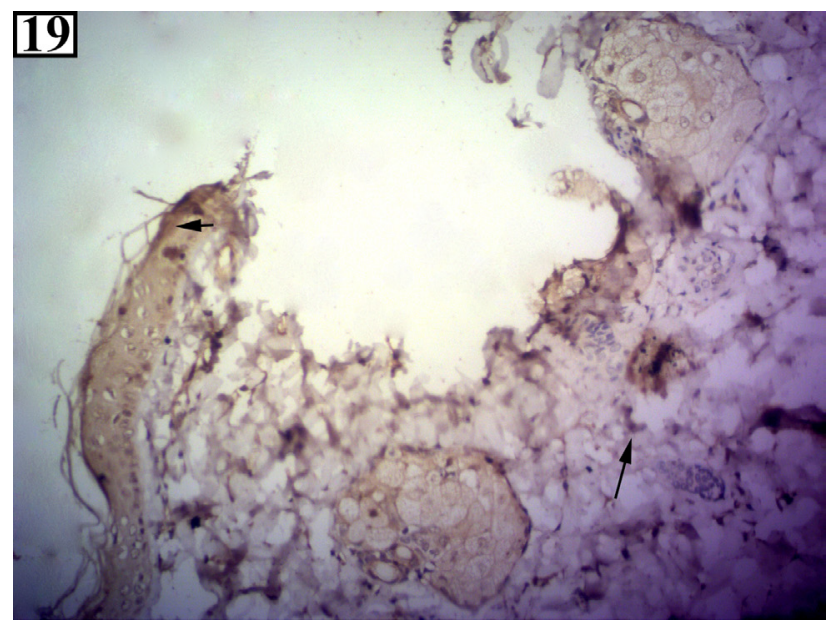

Fig. 19: A photomicrograph of a section in a diabetic skin wound of group III showing moderate positive cytoplasmic immunoreactivity for VEGF in keratinocytes (short arrow) and few cells of the dermis (arrow). (VEGF $\times 200)$

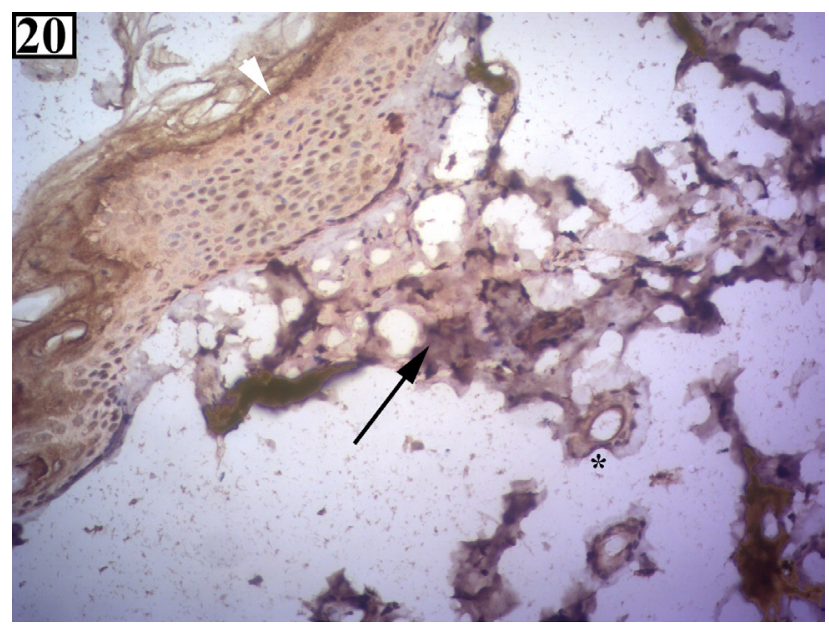

Fig. 20: A photomicrograph of a section in a diabetic skin wound of group III showing moderate positive cytoplasmic immunoreactivity for VEGF in keratinocytes (short arrow), in external root sheath of hair follicles $(*)$ and few cells of the dermis (arrow). $(\mathrm{VEGF} \times 200)$

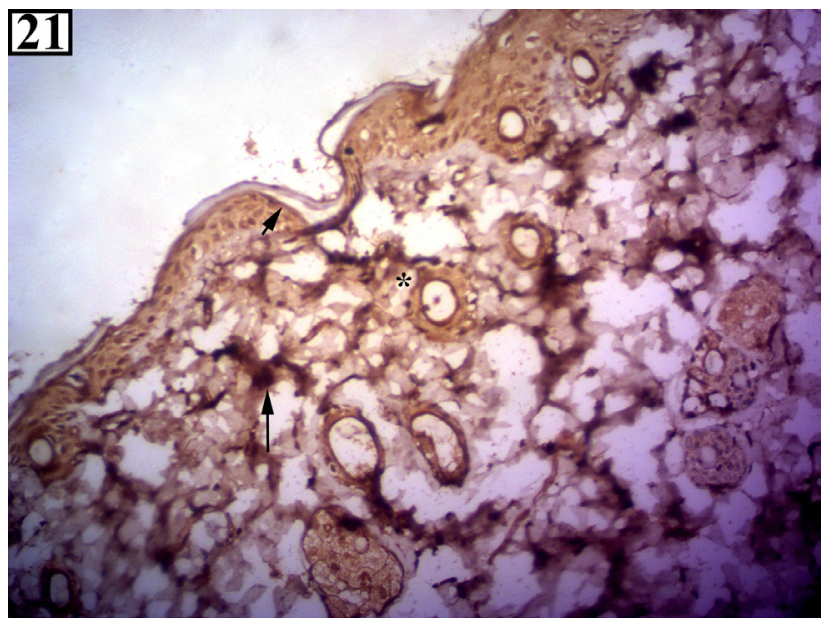

Fig. 21: A photomicrograph of a section in a diabetic skin wound treated with hesperidin of group IV showing very strong positive cytoplasmic immunoreactivity for VEGF in keratinocytes (short arrow), in the external root sheath of hair follicles $(*)$ and many cells of the dermis (arrow). $(\mathrm{VEGF} \times 200)$

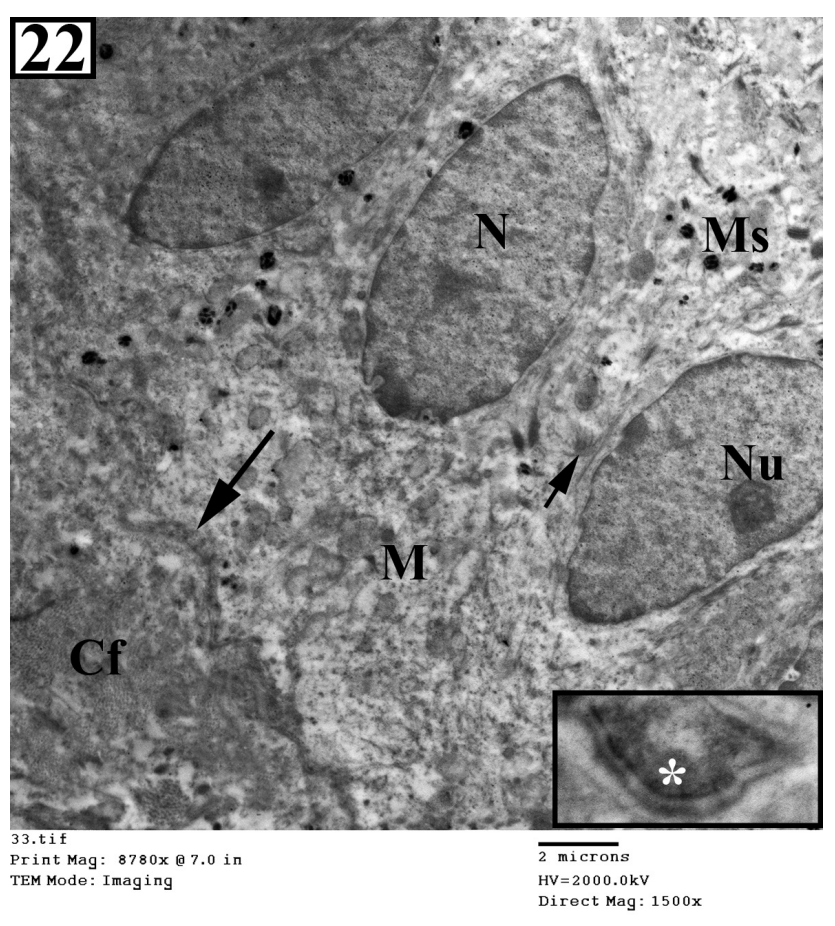

Fig. 22: An ultrathin section of control group (I) showing the stratum basale of the epidermis consisting of columnar basal cells arranged paralle to each other and resting on continuous basement membrane (arrow). They have regular euchromatic oval nuclei $(\mathrm{N})$ with prominent nucleoli $(\mathrm{nu})$ and their cytoplasm contains many mitochondria (M), intermediate keratin filaments (short arrow) and melanosomes (Ms). Collagen fibers are seen in dermis (Cf). Mag X 1500 Inset: hemidesmosome $(*)$ is seen Mag X 2000 


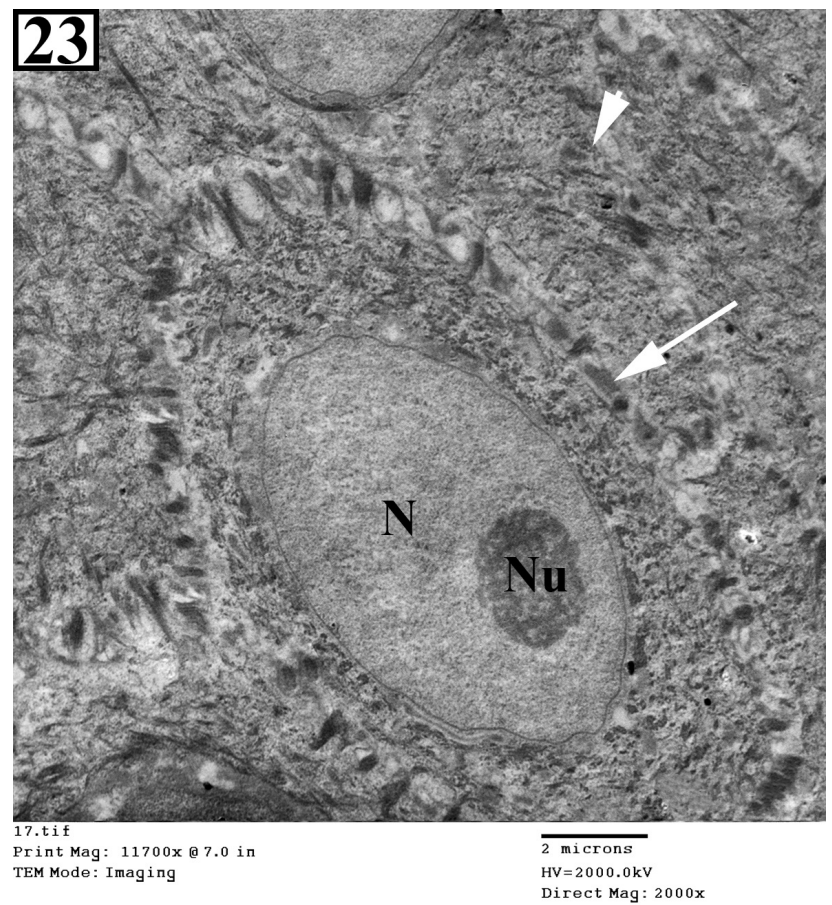

Fig. 23: An ultrathin section of control group (I) showing the stratum spinosum of the epidermis consisting of polygonal cells with oval euchromatic nuclei $(\mathrm{N})$, prominent nucleolus $(\mathrm{Nu})$ and bundles of tonofilaments in the cytoplasm (short arrow). Intact desmosomal junctions (arrow) between the spinous cells are observed. Mag X 2000

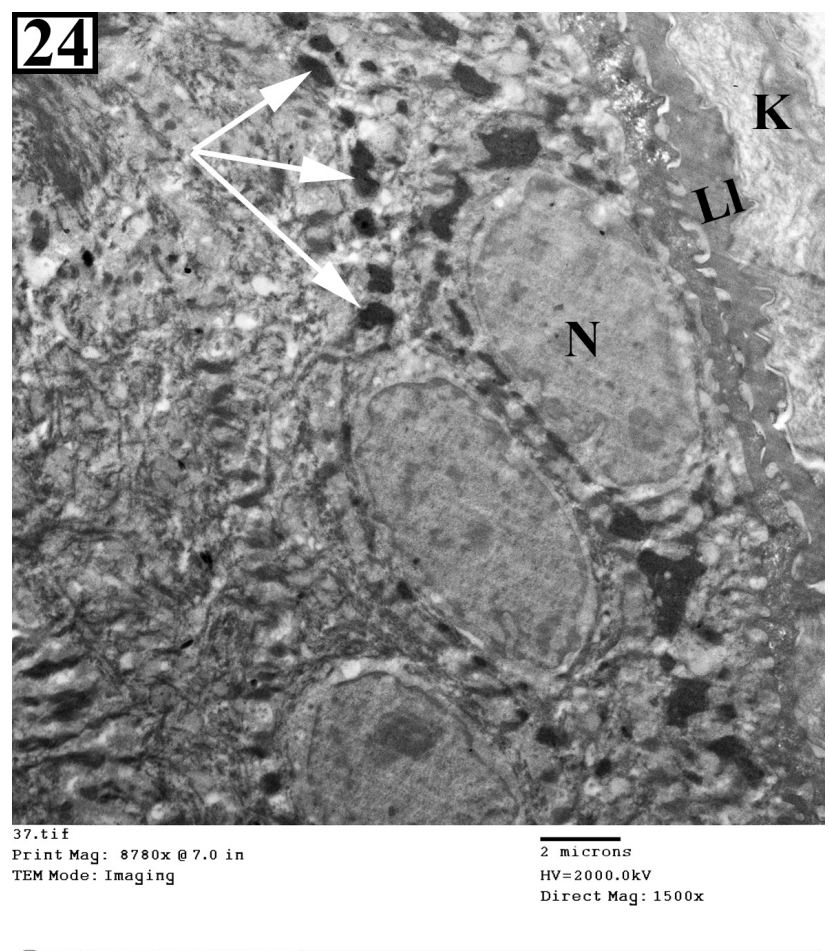

Fig. 24: An ultrathin section of control group (I) showing cells of stratum granulosum filled with variable sized electron dense keratohyalin granules (arrows). Their nuclei $(\mathrm{N})$ are oval and euchromatic. The st. corneum contains regular lamellae of keratin $(\mathrm{K})$. The stratum corneum-stratum granulosum interface shows multiple lipid lamellae (Ll). MagX1500

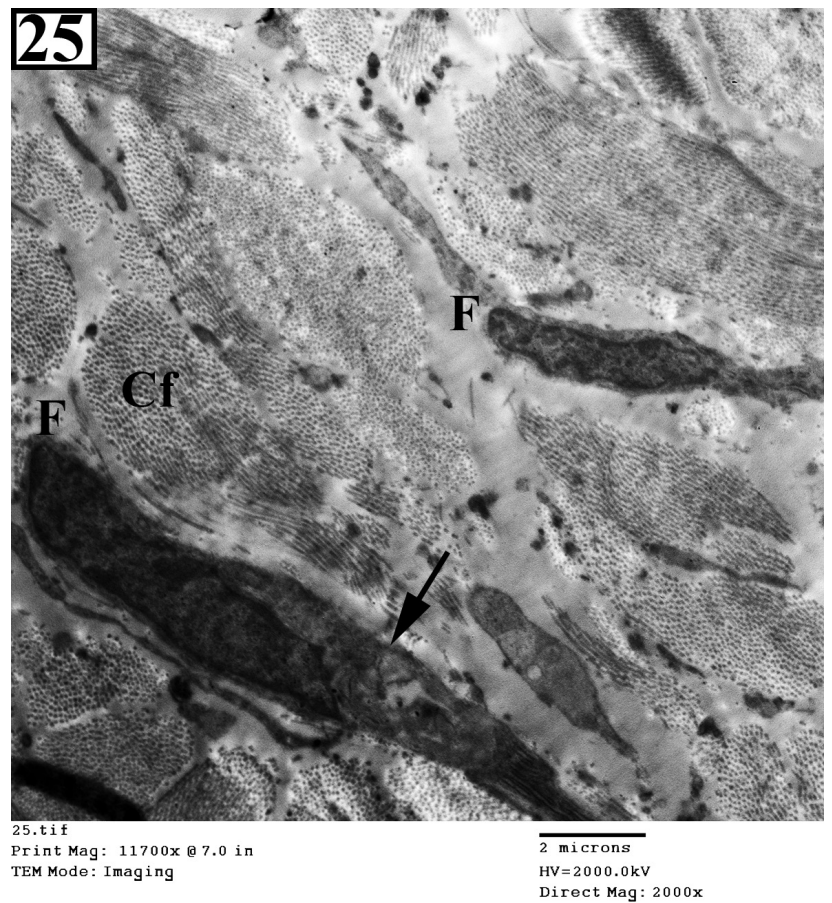

Fig. 25: An ultrathin section of the control group (I) showing spindleshaped fibroblasts (F) having euchromatic elongated nuclei with peripheral heterochromatin. Bundles of regular collagen fibers $(\mathrm{Cf})$ are seen surrounding the cells. One fibroblast (arrow) is observed in the process of releasing tropocollagen into the extracellular matrix. Mag X 2000

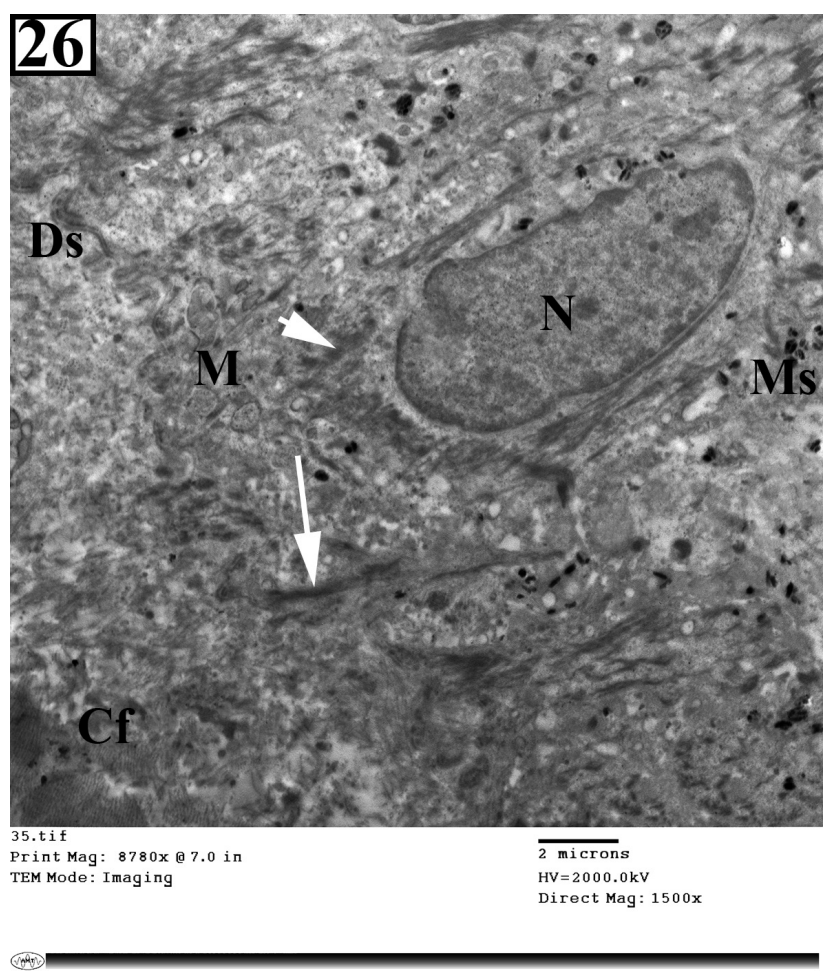

Fig. 26: An ultrathin section of hesperidin treated group (II) showing columnar basal cell with regular euchromatic oval nucleus $(\mathrm{N})$. The cytoplasm contains mitochondria $(\mathrm{M})$, intermediate keratin filaments (short arrow) and melanosomes (Ms). Note: regular basement membrane (arrow) with hemidesmosome (Ds) and organized collagen fibers (Cf) in dermis Mag X 1500 


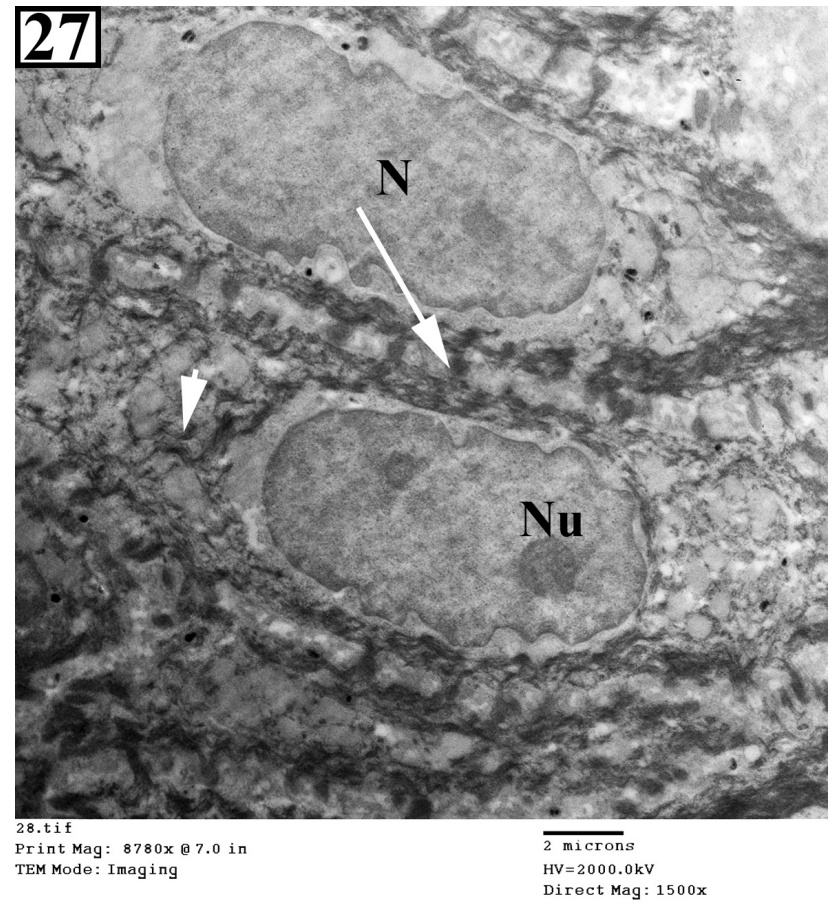

Fig. 27: An ultrathin section of a hesperidin treated group (II) showing the stratum spinosum of the epidermis consisting of spinous cells with oval nuclei $(\mathrm{N})$, nucleolus $(\mathrm{Nu})$, bundles of tonofilaments (short arrow) and intact desmosomal junctions (arrow). MagX1500

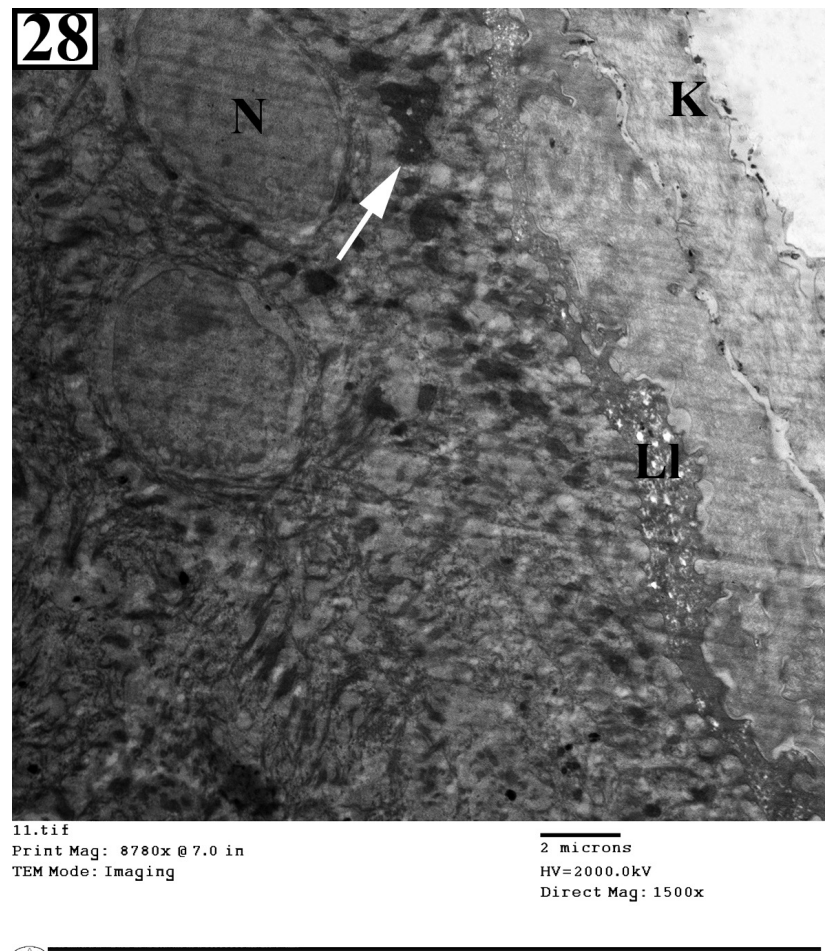

Fig. 28: An ultrathin section of a hesperidin treated group (II) showing cells of stratum granulosum with keratohyalin granules (arrow), nuclei (N), keratin (K) and lipid layer (L1). MagX1500

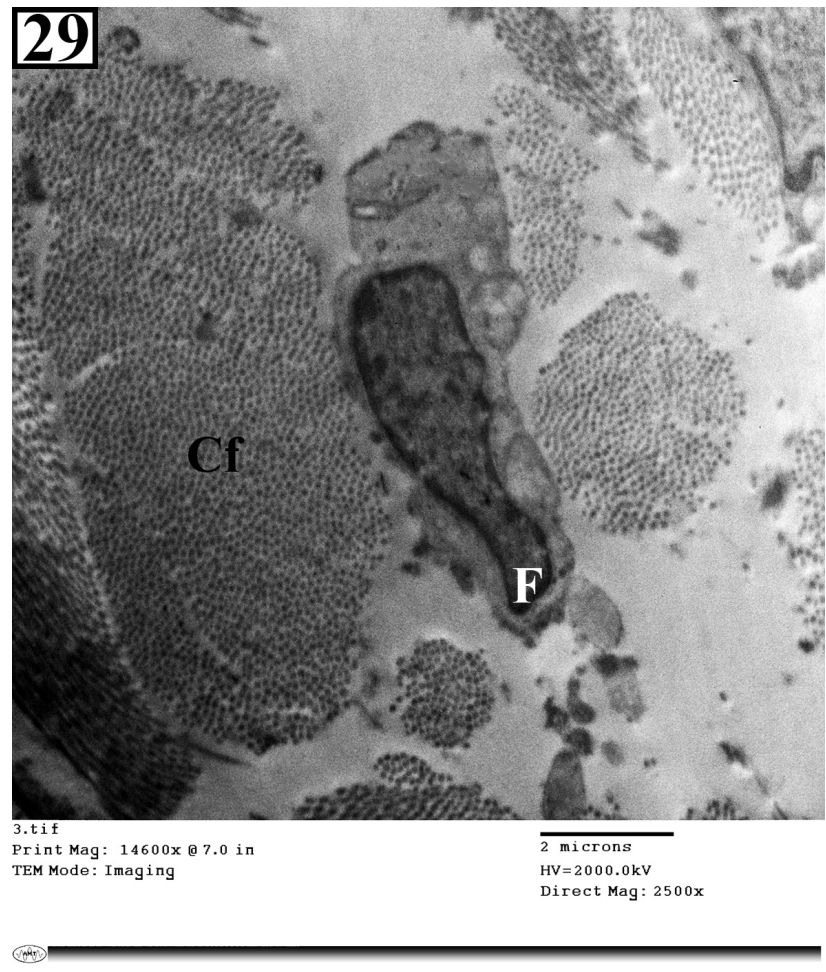

Fig. 29: An ultrathin section of the hesperidin treated group (II) showing fibroblast (F) and regular bundles of collagen fibers (Cf). Mag X 2500

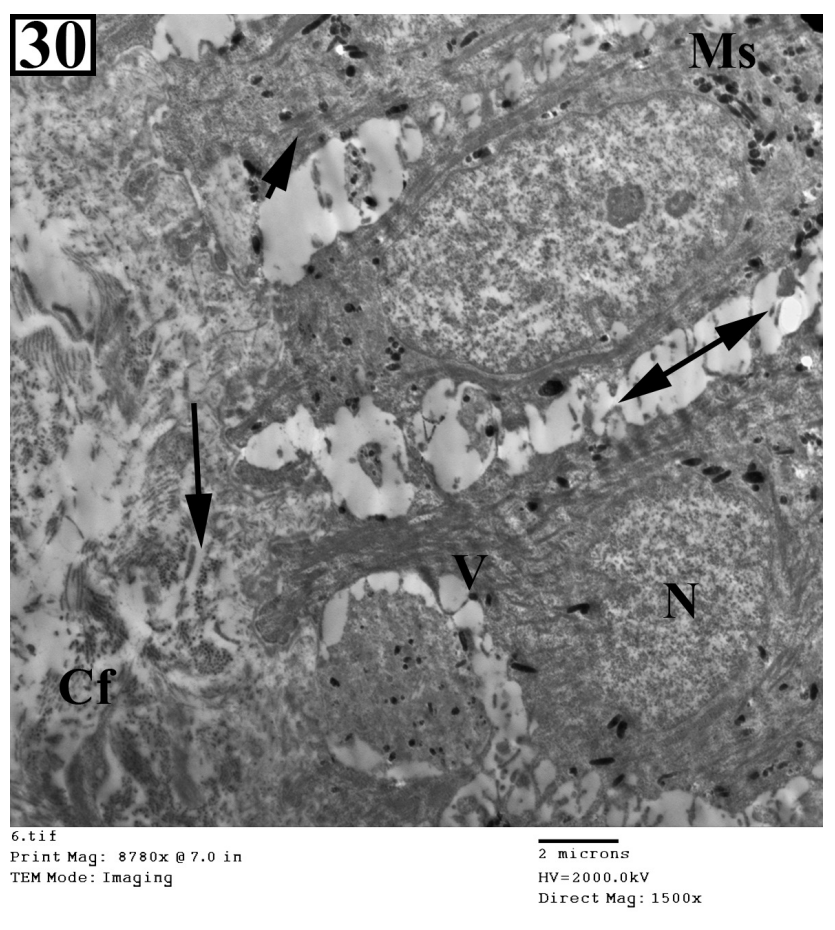

Fig. 30: An ultrathin section in untreated diabetic skin wound of group III showing the cells of the stratum basal with dilatation of the intercellular spaces and loss of cellular junctions (double head arrow). The cells rest on a discontinuous basement membrane (arrow). Their cytoplasm contains abundant keratin filaments (short arrow), irregular nucleus(N), melanosome granules (Ms) and electron-lucent cytoplasmic vacuoles (V). The underlying dermis contains excessive amount of disorganized collagen fibers (Cf). Mag X 1500 


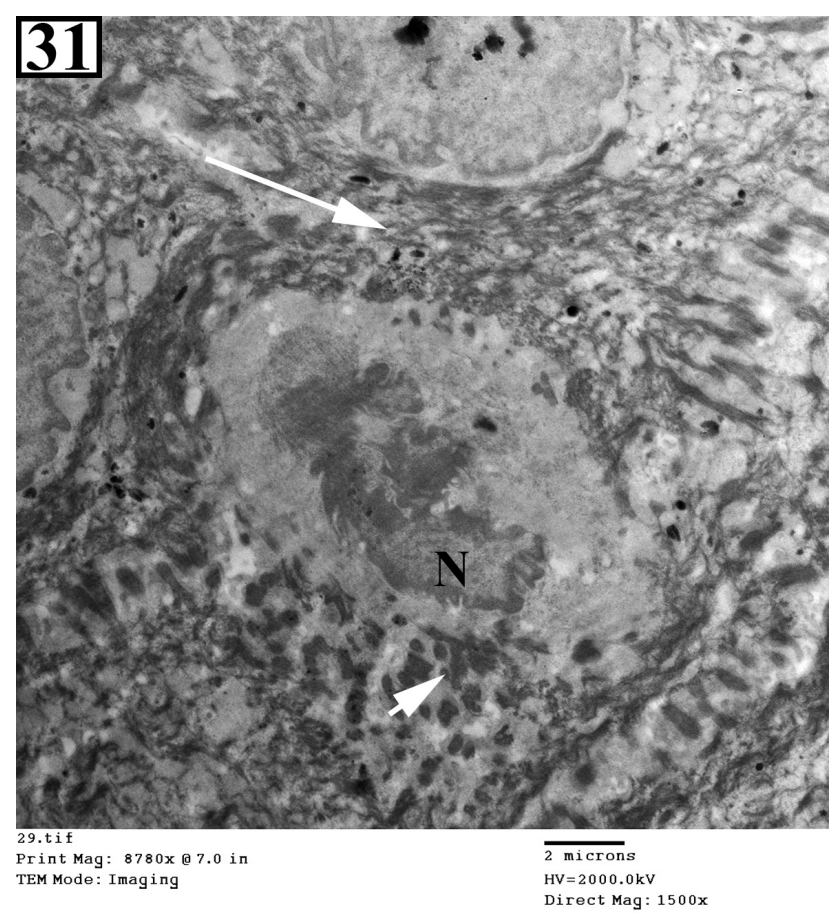

Fig. 31: An ultrathin section in untreated diabetic skin wound of group III showing a degenerated spinous cell with hyperchromatic shrunken irregular nucleus $(\mathrm{N})$ surrounded by electron-pale area. The cytoplasm contains many tonofilament bundles some of which appear fragmented and condensed (short arrow). Irregular desmosmal junctions (arrow) with the widening of intercellular space. Mag X 1500

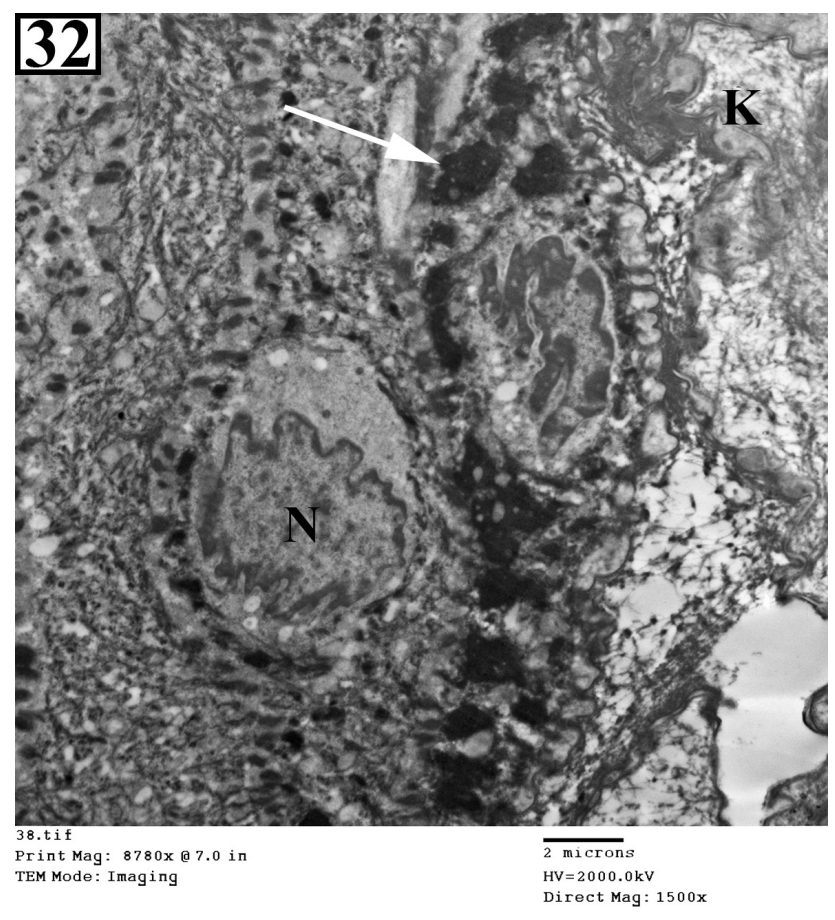

Fig. 32: An ultrathin section in untreated diabetic skin wound of group III showing the cells of stratum granulosum with abundant and enlarged keratohyalin granules (arrow). Their nuclei $(\mathrm{N})$ appears hyperchromatic with numerous indentations. Disrupted thickened stratum corneum $(\mathrm{K})$ is observed. Mag X 1500

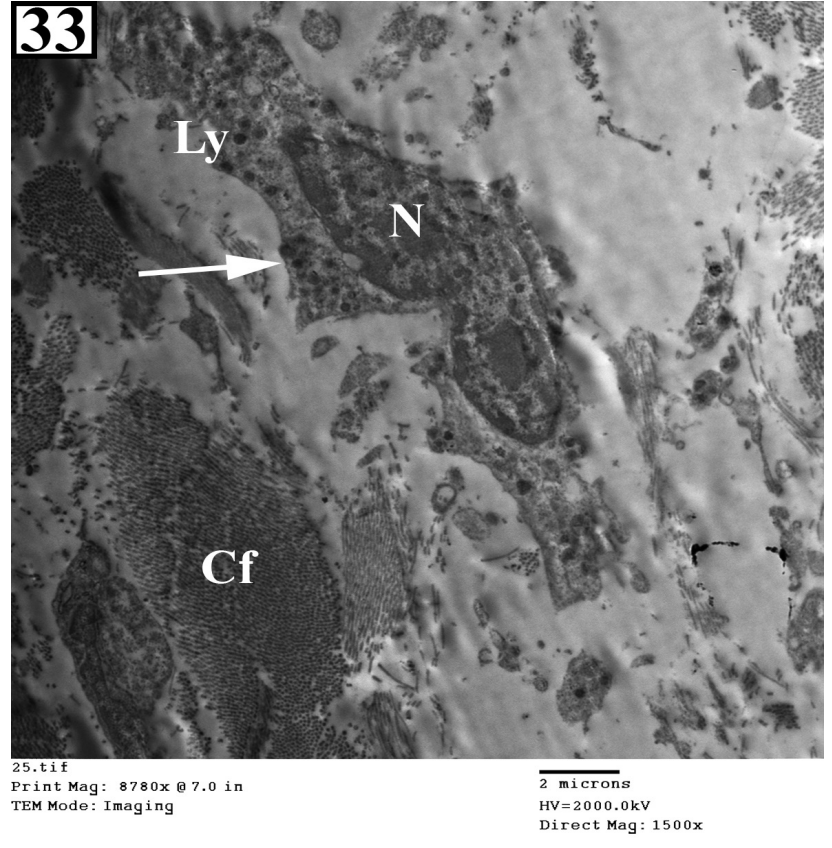

Fig. 33: An ultrathin section in untreated diabetic skin wound of group III showing macrophage in the dermis. The cell has a characteristic irregular surface with protrusions and indentations (arrow). Its nucleus $(\mathrm{N})$ is kidney shape with heterochromatin. The cytoplasm contains numerous lysosomes (Ly). Irregular bundles of collagen fibers (Cf) are seen in the dermis. Mag X 1500

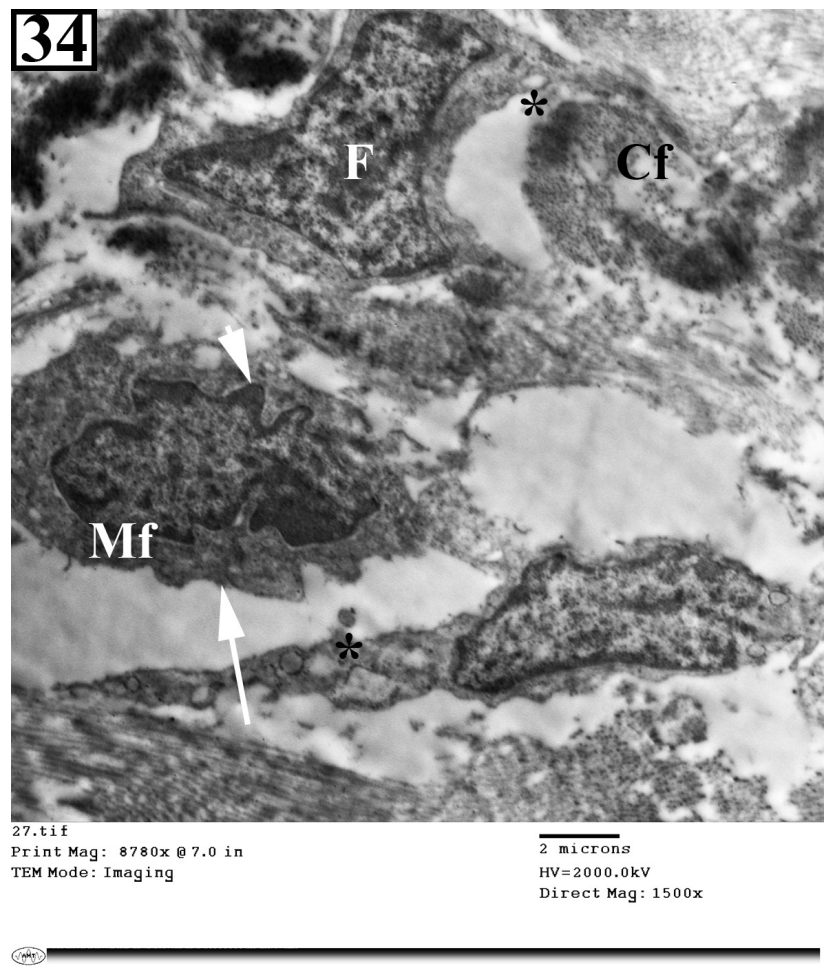

Fig. 34: An ultrathin section in untreated diabetic skin wound of group III showing a fibroblast (F) compressed by fluid accumulation with elongated euchromatic nucleus. Another fibroblast has numerous dilated cisternae of rough endoplasmic reticulum $(*)$. Myofibroblast (arrow) with its characteristic features is observed. It shows intracytoplasmic bundles of microfilaments (Mf) arranged peripherally in parallel to the axis of the cell, numerous nuclear indentations and deep folds (short arrow). Disorganized collagen fibers (Cf) are observed in dermis. Magx1500 


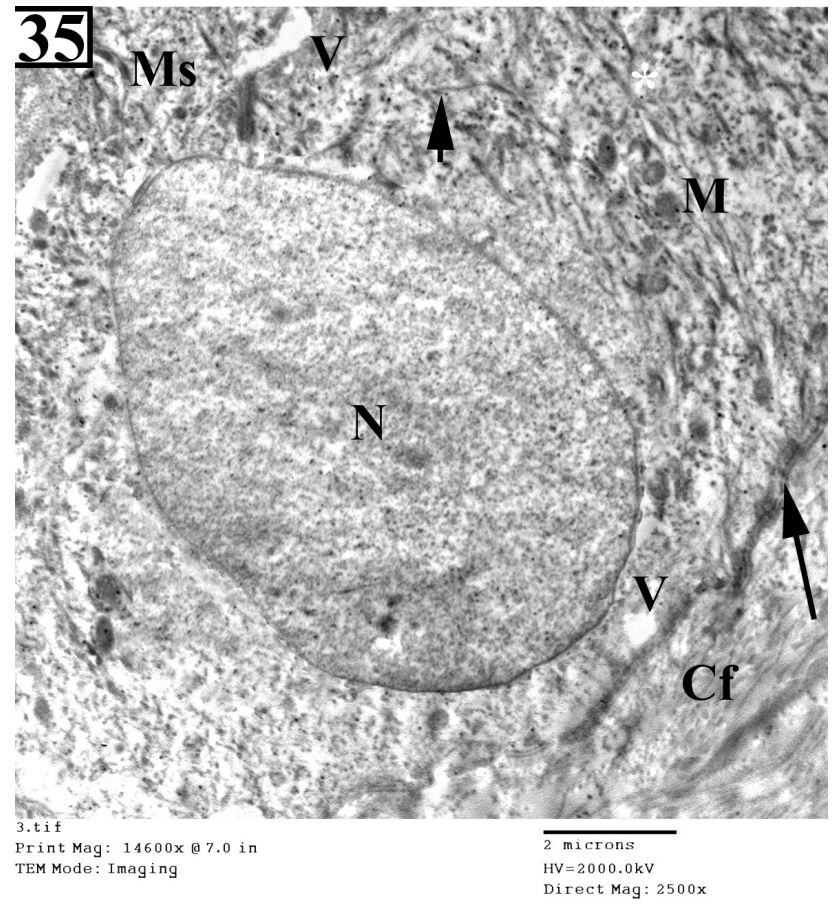

Fig. 35: An ultrathin section of diabetic skin wound treated with hesperidin of group IV showing columnar basal cell with regular euchromatic oval nucleus $(\mathrm{N})$. The cytoplasm contains mitochondria (M), intermediate keratin filaments (short arrow) and melanosomes (Ms). Regular basement membrane (arrow), intercellular junctions $(*)$ and organized collagen fibers (Cf) in dermis are seen. Note: small vacuoles (V) are still seen. Mag X 2500

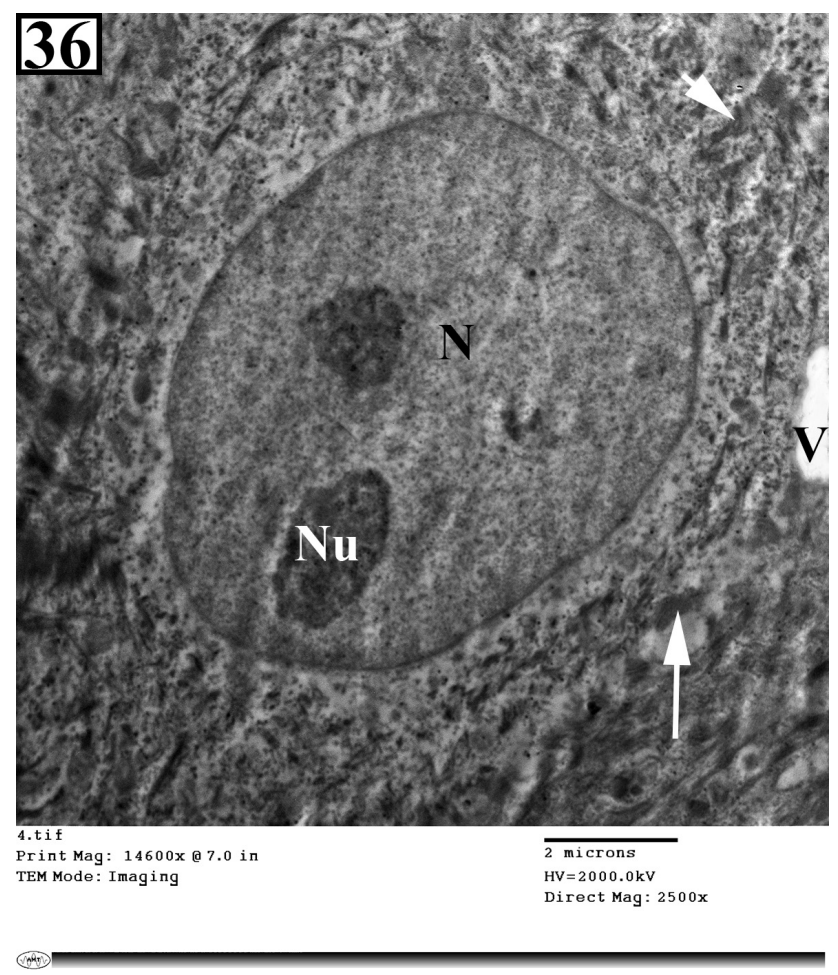

Fig. 36: An ultrathin section in diabetic skin wound treated with hesperidin of group IV showing spinous cells with oval nuclei $(\mathrm{N})$, nucleolus $(\mathrm{Nu})$, bundles of tonofilaments (short arrow) and intact desmosomal junctions (arrow). Note: small vacuoles(V) are still seen. MagX2500

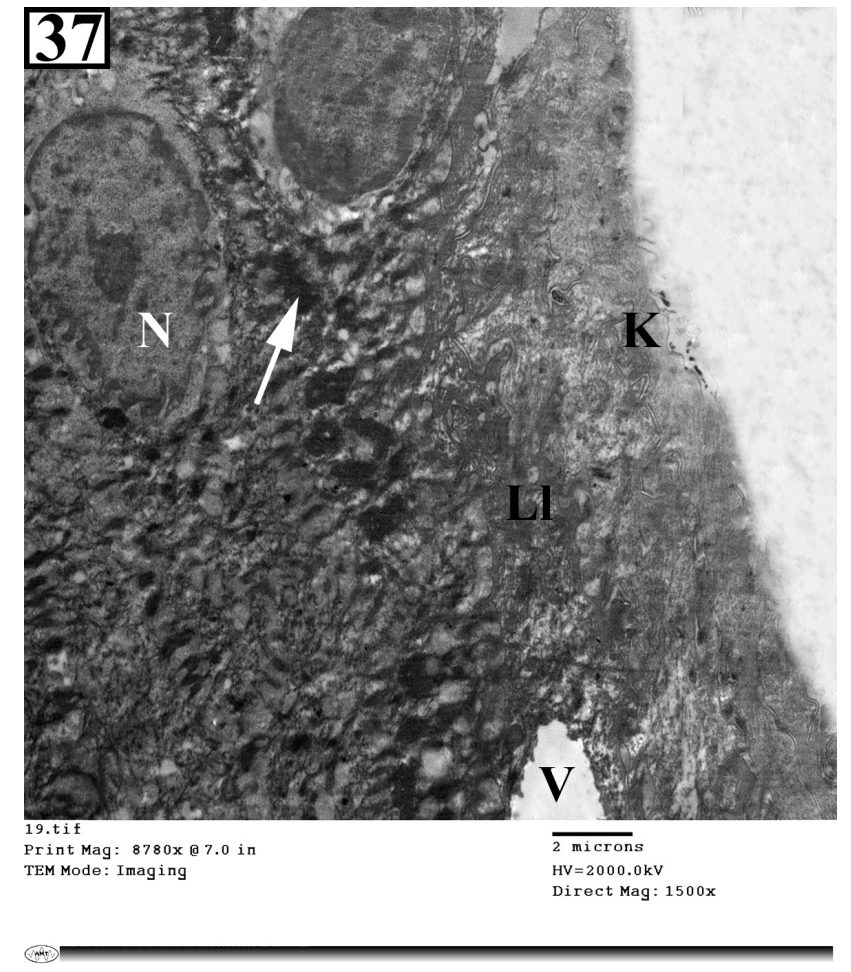

Fig. 37: An ultrathin section of a diabetic skin wound treated with hesperidin of group IV showing cells of stratum granulosum with keratohyalin granules (arrow), nuclei $(\mathrm{N})$, keratin $(\mathrm{K})$ and lipid layer (Ll). Note: small vacuoles(V) are still seen MagX1500

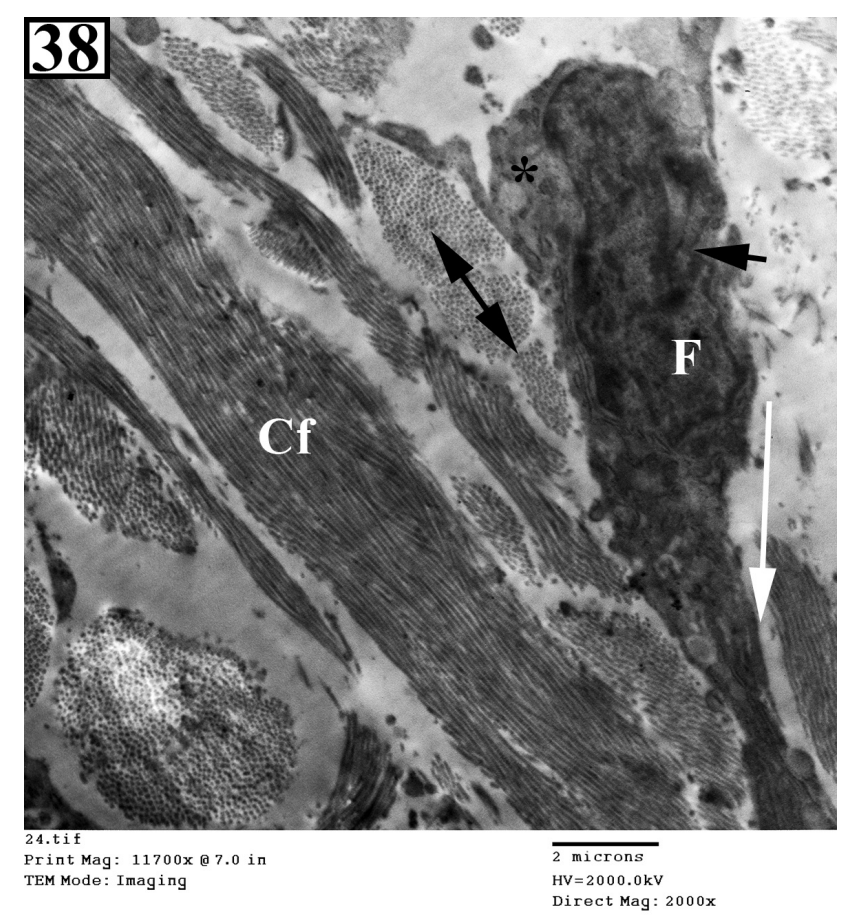

Fig. 38: An ultrathin section of a diabetic skin wound treated with hesperidin of group IV showing active fibroblast (F) with cytoplasmic processes (arrow). The cytoplasm shows few dilated rough endoplasmic reticulum (*) The nucleus shows indentations (short arrow). Bundles of regularly arranged collagen fibers $(\mathrm{Cf})$ are seen beside the cell, some of which have been cut in cross section and thus appear as small dots (double head arrow). Mag X 2000 


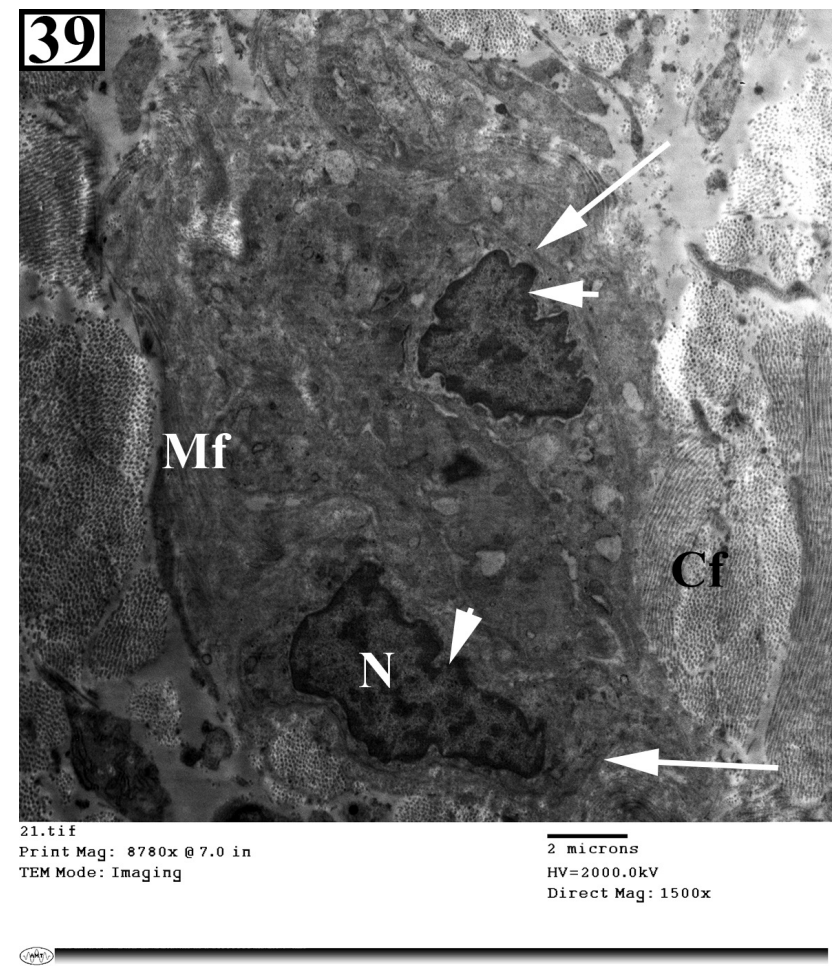

Fig. 39: An ultrathin section in diabetic skin wound treated with hesperidin of group IV showing two myofibroblast cells (arrows)with characteristics features. The cells show intracytoplasmic microfilaments (Mf) and numerous nuclear indentations and deep folds (short arrows). Regularly arranged collagen fibers are observed (Cf). Mag X 1500

Table 1: The epidermal thickness and the percentage area of collagen fibers in the control and experimental groups

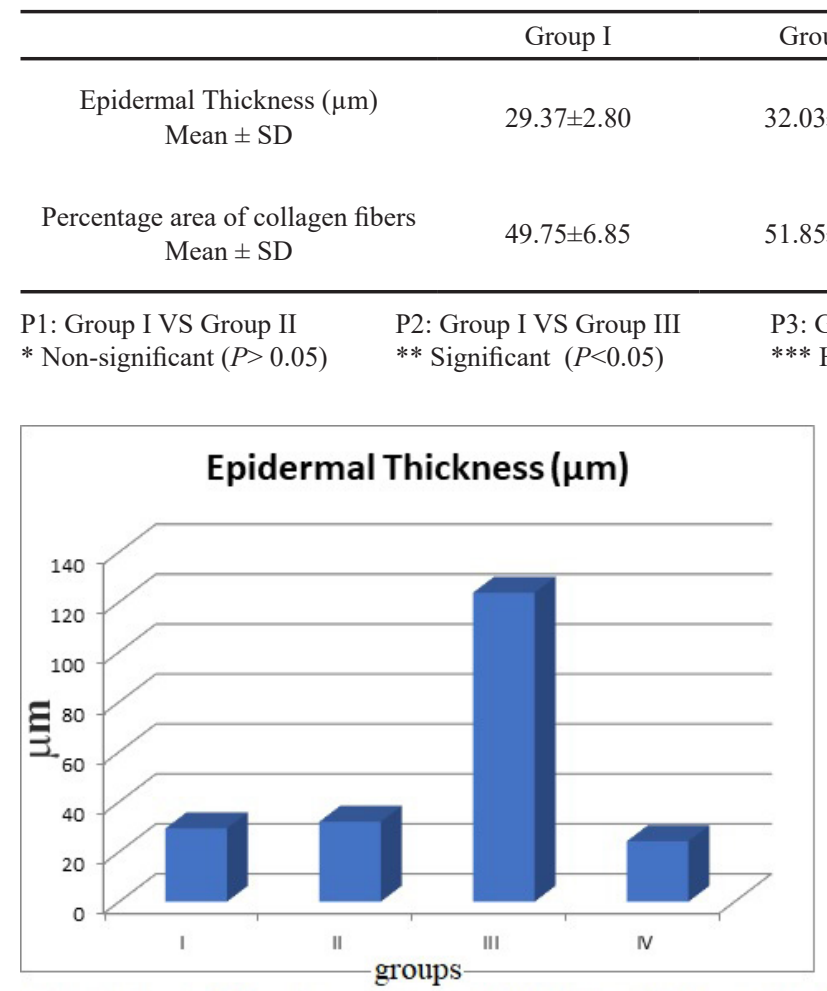

Histogram 1: The mean epidermal thickness in the control and experimental groups

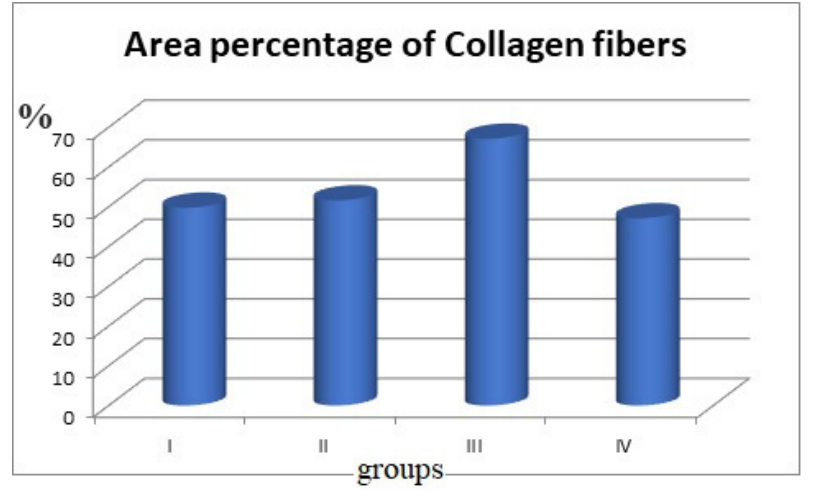

Histogram 2: The mean area\% of collagen fibers in the control and experimental groups 


\section{DISCUSSION}

Delayed or malformed wound healing is a multifactorial complication in diabetic patients resulting in severe stress and morbidity ${ }^{[20]}$.

There is a complicated sequence for skin repair which included clot formation, inflammation, proliferation and remodeling. Many cytokines and angiogenic factors are included in healing process ${ }^{[21]}$.

Delayed malformed healing of skin in diabetic patients may be due to combined factors as: elevated blood sugar, decreased insulin and growth hormone levels, diminished flow of blood, disorganized cell membrane permeability, abnormal collagen synthesis, increased reactive oxygen species (ROS) and apoptosis ${ }^{[22]}$.

Several mechanisms are included in malformed delayed skin healing in diabetes: (i) disturbed angiogenesis due to failure of formation of new blood vessels leading to poor oxygenation and nutritional supply. (ii) prolonged inflammation phase caused by inhibited immune system (iii) damage of extracellular matrix (ECM) by specific enzymes as matrix metalloproteases (MMPs) and (iv) elevated oxidative stress due to increasing free radicals in addition to decreasing levels of antioxidants ${ }^{[23]}$

Skin injuries in diabetic patient are still a challenge. Hence, there is an urgent need for more efficient therapy and restoration of skin function with good cosmetic results. Efficient therapy has to display impact through more than one mechanism of healing ${ }^{[20]}$. So, we have investigated the effects of hesperidin in STZ-induced diabetic ulcer.

Untreated diabetic rats in group III showed loss parts of skin (epidermis and dermis). The partially lost skin (wound) was covered by irregular scab. Scab formed of blood cells and fibrin to prevent further dehydration of the healing skin underneath and to protect it from infections. The epidermis proliferated forming epidermal tongue between the two edges of the wound. These findings were explained by previous study which stated that disturbances in the functions of inflammatory cells (migration and phagocytosis), release of lytic proteases, increased production of reactive oxygen species and apoptosis. Also, diminished entrance of new blood vessels into the wound area leaded to further limitation of inflammatory cells functions ${ }^{[24]}$.

In this study, although the epidermis was lost in some areas of skin of group III but it was completely malformed and thickened in other area due to increased cellular proliferation. These findings were previously mentioned in study discussed self- healed diabetic ulcer with acanthosis and hyperkeratosis ${ }^{[25]}$. This could be explained by release of proinflammatory cytokines like prostaglandins, leukotrienes, and interleukins ${ }^{[26]}$. Also, there was marked hypertrophy of the cells of stratum granuolosum with numerous and coarse basophilic keratohyalin granules. It may be a trial of tissue healing by release of growth factors to stimulate proliferation and migration of keratinocytes, fibroblast and macrophages cells into the injured area. This result was in agreement with previously published study ${ }^{[27]}$. Also, this finding was in harmony with statistical result that showed high significant increase of epidermal thickness in this group.

In support to our results, some researches added that epidermis of chronic wounds such as diabetic ulcers characterized by hyperproliferative epidermis as a result of overactivation and overexpression $^{[28]}$.

In addition, some epidermal cells had loss of polarity and surrounded by an eosinophilic hyaline material. It may be due to the rate of healing in diabetic wound may be decreased due to elevated levels of TNF- $\alpha$ and IL-6. These were in harmony with pervious study ${ }^{[20]}$.

The underlying dermis revealed disorganized collagen fibers and increased spaces between collagen fibers with invasion with inflammatory cells, these were in accordance with pervious research ${ }^{[24]}$. In confirmation to these results, the abnormalities in the formation of collagen protein at the wound area made healing process delayed and abnormal ${ }^{[20]}$.

The malformed healing in untreated diabetic group may be connected with an elevated number of inflammatory cells and absence of new blood vessels ${ }^{[29]}$. Neoangiogenic and granulating tissue were scarcely encountered in the diabetic ulcers $^{[25]}$. Also, absent new blood vessels were proved to occur during wound healing to trigger the formation of a blood clot causing hemostasis ${ }^{[30]}$.

Moreover, delayed malformed healing could be due to disturbance of oxygen concentration as a result of atherosclerosis in diabetic patients ${ }^{[20]}$.

Stem cells which presents in stem cell niches, regulate the proliferative activity of keratinocytes. There are three major niches: bulge of the hair follicle, the base of the sebaceous gland, and the basal layer of the epidermis ${ }^{[28]}$.

A pervious study added that stem cells have an essential role in regeneration of skin injuries but stem cells are deficient in diabetic patients so resulted in delayed malformed healing ${ }^{[31]}$. Also, another study recorded that adipocyte were activated during skin wound healing. They added that in skin wound healing, adipocyte proliferation is associated with fibroblast migration. They concluded that adipocytes are essential for fibroblast stimulation and skin rebuilding. So, fat cells are important as stem cells during wound healing ${ }^{[32]}$. This was in harmony with our study that detected the appearance of fat cells around hair follicles in group III.

Many hair follicles with absence of the associated sebaceous glands were observed in the dermis of group III These were in accordance with a pervious study ${ }^{[26]}$. It was explained by that vascular congestion in the dermis caused by vasodilator substances and the resulted stagnant blood will cause tissue hypoxia followed by degeneration of the hair follicles, sweat and sebaceous glands. Also, loss of the sympathetic tone could be the cause of disturbances in the vascular structure and function, especially capillaries leading to local ischemia and consequent decrease of the blood flow and nutrition to the tissues ${ }^{[26]}$. Although, hyperplasia 
of some hair follicles cells was noticed in some sections in group III and this was in agreement with a pervious study ${ }^{[27]}$ that explained this by its action as source of stem cells called follicular bulge.

The untreated diabetic rats stained with Mallory trichrome in group III revealed great amount of collagen fibers in dermis which appeared dense, thick, wavy and disorganized and this was in agreement with high significant raise in statistical study. Moreover, some collagen fibers were seen inside the epidermis. These findings were in harmony with a former research ${ }^{[25]}$ that detected hypertrophic dermis with a greater degree of fibrosis in the diabetic ulcer. It could be explained as a compensatory attempt to overcome the skin impairment by initial deposition of disorganized collagen filling the wound gap ${ }^{[24]}$. These results were in harmony with E.M. findings in group III and confirmed by former study ${ }^{[20]}$.

The untreated diabetic rats in group III revealed moderate positive immunoreactivity for VEGF in keratinocytes, in external root sheath of hair follicles and few cells of the dermis. Former studies confirmed that the inadequate raise in VEGF levels in diabetic tissue resulted from hypoxia ${ }^{[33]}$. It added that VEGF is essential for repair during impaired healing in diabetic and non-diabetic ischemia and VEGF blocking with neutralizing antibodies delays tissue repair ${ }^{[33]}$. Also, in support to our results, it was reported that VEGF is an angiogenetic factor that promote angiogenesis and revascularization ${ }^{[34]}$. It is produced by many cells such as keratinocytes, macrophages and fibroblasts and it is very essential for effective wound healing ${ }^{[11]}$.

Disturbed VEGF level results in increased activity of gap junction. This stimulates apoptotic, pro-inflammatory, and toxic signaling pathways from damaged area to surrounding healthy area via gap junctions that generate further healing impairment ${ }^{[20]}$.

Ultrathin sections of the untreated diabetic skin of group III showed the malformed healed part of the wound. The epidermis appeared thick in some areas especially stratum granulosum appeared with abundant and enlarged keratohyalin granules (hypergranulosis). The stratum corneum appeared with multiple disrupted lamellae of keratin. The cells revealed many tonofilament bundles and some filaments appeared fragmented and condensed. These EM results were in harmony with previously published research $^{[36]}$ which explained that by hyperstimulation of the keratinocytes to cover the injured bed and get back barrier function in the skin.

Also, their cytoplasm contained electron-lucent cytoplasmic vacuoles most probably swollen mitochondria with destroyed cristae. These results were in agreements with previously published research ${ }^{[26]}$ which stated that oxidative mitochondrial swelling may cause damage of the outer mitochondrial membrane and release of cytochrome $\mathrm{C}$ to activate the Proapoptotic Bax protein which stimulate apoptosis. So, some epidermal cells appeared with hyperchromatic shrunken irregular nuclei. Also, epidermal cells appeared resting on a discontinuous basement membrane and it could be explained by apoptosis ${ }^{[26]}$. In addition, these degenerative changes in keratinocytes could be explained by ischemia due to diabetes ${ }^{[24]}$.

Group III showed an abundance of dilated cisternae of rough endoplasmic reticulum of fibroblasts. This could be degenerative features due to oxidative stress by ROS [26]. Other cells in group III appeared with dilatation of the intercellular spaces and disrupted cellular junctions It could be explained as disrupted junctions are a necessary to decrease the adhesion between cells and allowing keratinocytes to migrate in an attempt of healing ${ }^{[28,34]}$.

Also, the dermis showed massive infiltration with inflammatory cells as macrophage and active fibroblasts. This finding was in in harmony with the results of previously published research ${ }^{[25]}$. In support to our results, it was confirmed that the fibroblasts proliferate and secrete many extracellular matrix proteins ${ }^{[26]}$.

They added that excessive deposition of collagen fibers by fibroblasts occurs due to chronic inflammatory reaction. Moreover, they have been suggested that macrophages may release fibroblast chemotactic factors leading to more fibroblast proliferation and more collagen deposition ${ }^{[26]}$.

At present, the knowledge of macrophage subpopulations is still growing as they are necessary in controlling infectious processes, but their presence is also necessary to maintain homeostasis. They are distinguished into M1 and M2 macrophages up till now. The M1 macrophages are characterized by the generation of high levels of proinflammatory cytokines and antimicrobial functions. In contrast, M2 macrophages are characterized by their involvement in tissue remodelling and immune regulation. So, in chronic lesion as diabetic ulcer M1 may convert to M2 in an attempt of healing ${ }^{[35]}$.

Also, the dermis revealed myofibroblast cells with characteristic features. The fibroblasts and myofibroblasts have an essential role to produce an organized network of collagen fibers and other ECM proteins ${ }^{[36]}$. Early during wound healing, fibroblasts proliferate and differentiate to myofibroblasts, these happen due to mechanical stress and cytokines especially transforming growth factor- $\beta^{[28]}$. This transformation results in increased collagen synthesis and contraction of edges of wound. Myofibroblasts could stimulate endothelial cells proliferation ${ }^{[30]}$. Healing of injured tissue could be disorganized because myofibroblasts precipitate too much amounts of ECM protein as collagen in the form of fibrosis ${ }^{[37]}$.

Group IV revealed complete closure of the injuries in all sections. There was complete re-epithelization with apparently normal epithelium. The epidermis appeared thin with flattening of the dermo-epidermal junction as match with statistical result that showed significant decrease in epidermal thickness of this group when compared with control. This was in harmony with pervious study ${ }^{[20]}$ then it added that hesperidin decreases blood sugar level, stimulates fibroblasts proliferation and enhances angiogenesis and this may fasten the healing of diabetic wound. 
The underlying dermis of group IV revealed well organized fibers with newly formed blood vessels reflecting the occurrence of angiogenesis and vasculogenesis. Also, the dermis had hair follicles and sebaceous glands nearly similar to control. These were in accordance with pervious research ${ }^{[20]}$ which explained that by decreasing of cytokines as TNF- $\alpha$ and IL- 6 and thus increasing wound healing and added that only hesperidin acts on more than one healing mechanism.

Also, neovascularization observed in group IV was attributed to the significantly increased amounts of ANG1 (angiopoietin) and vascular endothelial growth factor in the wounds, which is very important in stimulating endothelial cell proliferation, migration, and organization into tubules ${ }^{[38,39]}$.

In our study, the diabetic rats were left for 30 days then specimens were taken. This duration was recorded because of 30 days post wound were needed for full differentiation of the newly formed epidermis ${ }^{[11]}$. Matrix formation progresses more slowly and the process of keratinocyte differentiation appears to occur at the same time of the dermal closure. This has ensured good quality of wound healing regaining strength and elasticity of the $\operatorname{skin}^{[11]}$.

In Group IV, the dermal collagen fibers appeared well organized and nearly normal in amount by Mallory stain. These were in agreement with pervious study ${ }^{[20]}$ which explained this improvement by antioxidant effects of hesperidin $^{[40]}$.

Group IV revealed very strong positive immunoreactivity of VEGF in keratinocytes, in external root sheath of hair follicles and many cells of the dermis. This could be explained by that hesperidin can stimulate VEGF gene ${ }^{[40]}$. VEGF is known as the most dynamic and special growth factor that controls angiogenesis ${ }^{[41]}$. Also, in support to our results, some studies added that VEGF has role in enhancement of skin injuries in diabetic mice which is mediated via stimulation and recruitment of endothelial bone marrow-derived progenitor cells ${ }^{[33]}$. In addition, VEGF increases epithelialization and collagen deposition and enhances cellular proliferation ${ }^{[40]}$.

Ultrathin sections of the diabetic skin treated with hesperidin showed the newly formed epidermis covering the injured area. The epidermal cells had ultrastructural features nearly like those of the control group. This was in agreement with previous research ${ }^{[9]}$ which confirmed that hesperidin extends an antioxidant effect through scavenging free radicals or via stimulating cellular antioxidant enzyme systems.

The underlying dermis in group IV showed regularly arranged collagen fibers and active fibroblasts this could be explained by that hesperidin can lower cytokine production $^{[10]}$. But few numbers of inflammatory cells infiltration and spaces are still present.

\section{CONCLUSION}

Histological examination of wound model in diabetic rats reveal that skin injuries are healing badly in relatively prolonged time. Hesperidin has an effective cosmetic healing effects on injured skin. So, hesperidin can be used as an adjunctive or alternative agent in wound healing therapies in future. However, further studies are certainly needed to spot more light on the healing mechanism of hesperidin. Therefore, the application of hesperidin treatment raises the hopes for developing a new, safe and effective therapy for diabetic ulcer patients.

\section{RECOMMENDATION}

- Usage of hesperidin for more prolonged time to achieve full remodelling of the epidermis and dermis.

- Usage of different concentrations of hesperidin and compare their results.

\section{CONFLICT OF INTERESTS}

There are no conflicts of interest.

\section{REFERENCES}

1. Patel S, Srivastava S, Singh MR and Singh D. Mechanistic insight into diabetic wounds: Pathogenesis, molecular targets and treatment strategies to pace wound healing. Biomedicine and Pharmacotherapy. (2019); 112: 108615.

2. Ibrahim NA. Evaluation of the effect of bee propolis cream on wound healing in experimentally induced type I diabetes mellitus: a histological and immunohistochemical study. Egypt J Histol. (2013); 36(4): 847-856.

3. Naim MM, El Sharawy M and Greish SM. Stem cells promote healing of experimentally induced ulcer in streptozotocin diabetic rats: histological and immunohistochemical study. Egypt J Histol. (2011); 34(2): 323-332.

4. Liu W, Ma K, Kwon SH, Garg R, Patta YR, Fujiwara $\mathrm{T}$ and Gurtner GC. The Abnormal Architecture of Healed Diabetic Ulcers Is the Result of FAK Degradation by Calpain 1. J Invest Dermatol. (2017); 137(5): 1155-1165.

5. Park JH, Choi SH, Park SJ, Lee YJ, Park JH, Song $\mathrm{PH}$, Cho CM, Ku SK and Song CH. Promoting Wound Healing Using Low Molecular Weight Fucoidan in a Full-Thickness Dermal Excision Rat Model. Mar Drugs. (2017); 15(4).

6. Zheng Y, Zheng S, Fan X, Li L, Xiao Y, Luo P, Liu Y, Wang L, Cui Z, He F, Liu Y, Xiao S and Xia Z. Amniotic Epithelial Cells Accelerate Diabetic Wound Healing by Modulating Inflammation and Promoting Neovascularization. Stem Cells Int (2018); 2018: 1082076. 
7. Bernardi S, Severini GM, Zauli G and Secchiero P. Cell-Based Therapies for Diabetic Complications. Experimental Diabetes Research. (2012); 2012, 872504, 10 pages.

8. Musa AE, Omyan G, Esmaely F and Shabeeb D. Radioprotective Effect of Hesperidin: A Systematic Review. Medicina (Kaunas). (2019); 55(7).

9. Jagetia GC and Rao KVNM. Hesperidin, a Citrus Bioflavonoid Potentiates Repair and Regeneration of Deep Dermal Excision Wounds of Mice Whole Body Exposed to Different Doses of 60Co $\gamma$-Radiation. Clin Dermatol J. (2018); 3(2): 000147.

10. Man MQ, Yang B and Elias PM. Benefits of Hesperidin for Cutaneous Functions. Evid Based Complement Alternat Med. (2019); 2019:2676307.

11. Ahmed OM, Mahmoud AM, Abdel-Moneim A and Ashour MB. Antidiabetic Effects of Hesperidin and Naringin In Type 2 Diabetic Rats. Diabetologia Croatica. (2012); 41(2): 53-67.

12. Srivivasan A, Menon VP, Periaswamy V and Rajasekaran KN. Protection of pancreatic beta-cell by the potential antioxidant bis-o-hydroxycinnamoyl methane, analogue of natural curcuminoid in experimental diabetes. J Pharm Pharm Sci. (2003); 6(3):327-333.

13. Wohaieb SA and Godin DV. Alterations in free radical tissue-defense mechanisms in streptozocininduced diabetes in rat. Effects of insulin treatment. Diabetes. (1987); 36(9):1014-1018.

14. Shi X, Liao S, Mi H, Guo C, Qi D, Li F, Zhang C and Yang Z. Hesperidin prevents retinal and plasma abnormalities in streptozotocin-induced diabetic rats. Molecules. (2012); 17(11):12868-12881.

15. Nakatsu N, Igarashi $Y$, Aoshi T, Hamaguchi I, Saito M, Mizukami T, Momose H, Ishii KJ and Yamada $\mathrm{H}$. Isoflurane is a suitable alternative to ether for anesthetizing rats prior to euthanasia for gene expression analysis. J Toxicol Sci. 2017;42(4):491-497.

16. Kiernan JA. (2015). Histological and histochemical methods; theory and practice. pp. 238-310. $5^{\text {th }} \mathrm{ed}$, Scion Publishing Ltd, Banbury, UK

17. Boujendar S, Arany E, Hill D, Remacle C and Reusens B. Taurine supplementation of a low protein diet fed to rat dams normalizes the vascularization of the fetal endocrine pancreas. $J$ Nutr. (2003); 133(9): 2820-2825.

18. Bozzola JJ. Conventional specimen preparation techniques for transmission electron microscopy of cultured cells. Methods Mol Biol. (2014); 1117:1-19.
19. Dawson B and Trapp RG. Basic and clinical biostatistics. 3rd ed. New York: Lane Medical Books/McGraw Hill; (2001).

20. Li W, Kandhare AD, Mukherjee AA and Bodhankar SL. Hesperidin, a plant flavonoid accelerated the cutaneous wound healing in streptozotocin-induced diabetic rats: Role of TGF- $3 /$ Smads and Ang-1/Tie2 signaling pathways. EXCLI J. (2018); 17:399-419.

21. Chen X, Zhou W, Zha K, Liu G, Yang S, Ye S, Liu $\mathrm{Y}$, Xiong Y, Wu Y and Cao F. Treatment of chronic ulcer in diabetic rats with self-assembling nanofiber gel encapsulated-polydeoxyribonucleotide. Am J Transl Res. (2016); 8(7): 3067-3076.

22. Wang L, He T, Fu A, Mao Z, Yi L, Tang S and Yang J. Hesperidin enhances angiogenesis via modulating expression of growth and inflammatory factor in diabetic foot ulcer in rats. European Journal of Inflammation. (2018); 16.

23. Soliman AM, Lin TS, Ghafar NA and Das S. Virgin coconut oil and diabetic wound healing: histopathological and biochemical analysis. Eur J Anat, (2018); 22 (2): 135-144.

24. Mohammed SAA, Moussa MH, Shaker SM and Elsherif SA. The effect of bone marrowderived mesenchymal stem cells on the healing of experimental skin wound in diabetic adult male albino rats. Egyptian Journal of Histology. (2014); 37(2):360-372.

25. Piaggesi A, Viacava $P$, Rizzo L, Naccarato G, Baccetti F, Romanelli M, Zampa V and Del Prato S. Semiquantitative analysis of the histopathological features of the neuropathic foot ulcer: effects of pressure relief. Diabetes Care. (2003); 26(11):3123-3128.

26. Al-Hamdany MZ, Al-Hubaity AY and Al-Omary MS. The Histological Changes of the Skin Lesion in Diabetic Foot. Global Journal of Medical Research: C Microbiology and Pathology. (2016); 16(1) Version 1.0.

27. Mansy AE, Faruk EM and Abo El khair W. Do stem cells promote healing of experimentally induced wound injury in adult male dogs? Histological and immunohistochemical study. The Egyptian Journal of Histology, (2013); 36(3):519-527.

28. Pastar I, Stojadinovic O, Yin NC, Ramirez H, Nusbaum AG, Sawaya A, Patel SB, Khalid L, Isseroff RR and Tomic-Canic M. Epithelialization in Wound Healing: A Comprehensive Review. Adv Wound Care (New Rochelle). (2014); 3(7):445-464.

29. Muhammad AA, Arulselvan P, Cheah PS, Abas F and Fakurazi S. Evaluation of wound healing properties of bioactive aqueous fraction from Moringa oleifera Lam on experimentally induced diabetic animal model. Drug Des Devel Ther. (2016); 10: 1715-1730. 
30. Ismail DI and Aboulkhair AG. Histological Evaluation of the Emerging Role of Adipose Stem Cells-Derived Exosomes in Cutaneous Wound Healing in Albino Rats. The Egyptian Journal of Histology, (2018); 41(4):459-472.

31. Cianfarani F, Toietta G, Di Rocco G, Cesareo E, Zambruno $G$ and Odorisio T. Diabetes impairs adipose tissue-derived stem cell function and efficiency in promoting wound healing. Wound Repair Regen. (2013); 21(4): 545-553.

32. Schmidt BA and Horsley V. Intradermal adipocytes mediate fibroblast recruitment during skin wound healing. Development. (2013); 140(7):1517-1527.

33. Badr G, Hozzein WN, Badr BM, Al Ghamdi A, Saad Eldien HM and Garraud O. Bee Venom Accelerates Wound Healing in Diabetic Mice by Suppressing Activating Transcription Factor-3 (ATF-3) and Inducible Nitric Oxide Synthase (iNOS)-Mediated Oxidative Stress and Recruiting Bone MarrowDerived Endothelial Progenitor Cells. J Cell Physiol. (2016); 231(10):2159-2171.

34. Tan WS, Arulselvan P, Ng SF, Mat Taib CN, Sarian $\mathrm{MN}$ and Fakurazi S. Improvement of diabetic wound healing by topical application of Vicenin-2 hydrocolloid film on Sprague Dawley rats. BMC Complement Altern Med. (2019); 19(1):20.

35. Lee KY. M1 and M2 polarization of macrophages: a mini-review. Med Biol Sci Eng. 2019;2(1):1-5.
36. Das $\mathrm{S}$ and Baker AB. Biomaterials and Nanotherapeutics for Enhancing Skin Wound Healing. Front Bioeng Biotechnol. (2016); 4:82.

37. Zeisberg $\mathrm{M}$ and Kalluri R. Cellular mechanisms of tissue fibrosis. 1. Common and organ-specific mechanisms associated with tissue fibrosis. Am J Physiol Cell Physiol. (2013); 304(3):C216-C225.

38. Wu Y, Chen L, Scott PG and Tredget EE. Mesenchymal stem cells enhance wound healing through differentiation and angiogenesis. Stem Cells. (2007); 25(10):2648-2659.

39. Eldrieny EA, Sarhan NI, Laag EM and Badr SM. Histological study of the effect of bone marrowderived mesenchymal stem cells on healing of skin defect in adult male albino rats. The Egyptian Journal of Histology. (2014); 37(1):186-196.

40. Haddadi G, Abbaszadeh A, Mosleh-Shirazi MA, Okhovat MA, Salajeghe A and Ghorbani Z. Evaluation of the effect of hesperidin on vascular endothelial growth factor gene expression in rat skin animal models following cobalt-60 gamma irradiation. J Cancer Res Ther. (2018); 14(Supplement):S1098-S1104.

41. Shi R, Jin Y, Cao C, Han S, Shao X, Meng L, Cheng J, Zhang M, Zheng J, Xu J and Li M. Localization of human adipose-derived stem cells and their effect in repair of diabetic foot ulcers in rats. Stem Cell Research \& Therapy (2016) 7(1):155. 
الملخص العربى

\title{
دور الههبريدين فى إلتئام الجروح القطعية المحدثة في ذكور الجرذان البيضاء البالغة

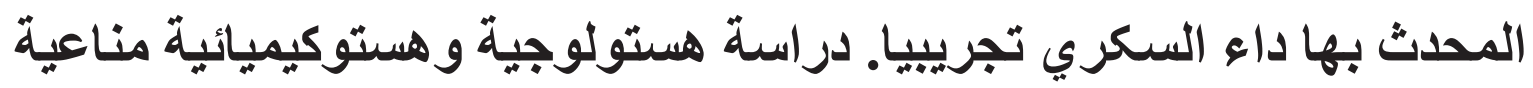

\author{
رانيا ابراهيم ياسين وداليا السيد الغزولى
}

\section{قسم الهستولوجيا وبيولوجيا الخليةـ كلية الطب -جامعة المنوفيةـ مصر}

الخلفية: تقرحات الجلد والضعف في الالتئام من المشكلات الخطيرة التي نواجه مرضي السكري. وجد ان منتجات الاعثاب الحمضية و اعدة في در اسات جديدة. اتضح ان للهسبريدين فو ائد متعددة فيما يخص وظائف الجلد ومنها التئام الجروح. هدف الدراسة: كان الهدف من هذا العمل هو تقييم التأثير الهحتمل للهببريدين في احداث التئام لإصابات الجلد في ذكور

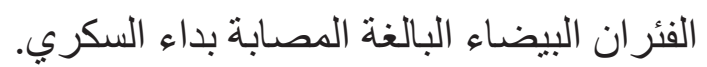
مواد وطرق البحث: تم تقسيم أربعين من ذكور الفئر ان البيضاء البالغة بشكل عشوائي إلى أربع مجموعات منساوية

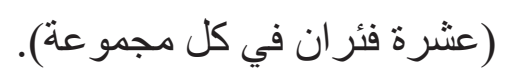
ـ المجمو عة الأولي: الضابطة.

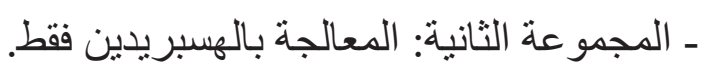

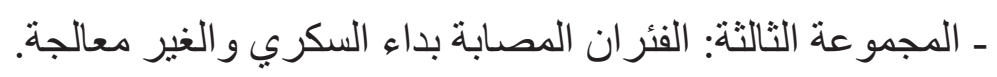

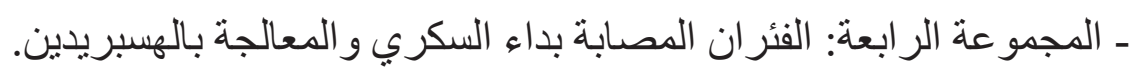
تم الحصول على عينات الجلد ثم تحضير ها من أجل در اسة هستولوجية باستخدام الهيماتوكسلين و الايوسين، مالوري الماني

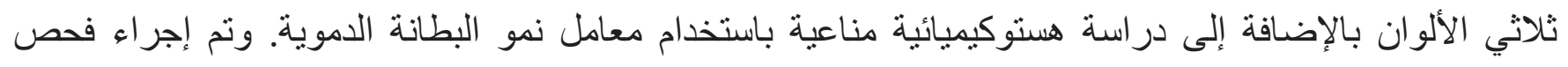

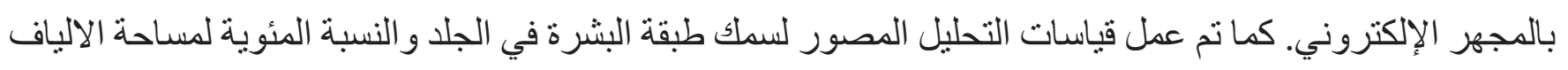
الكو لاجينية متبو عة بالتحليل الإحصائي. النتائج: أظهرت المجموعة المصابة بداء السكري والغير معالجة التئام غير كامل وقشرة تغطي البشرة المتكاثرة.

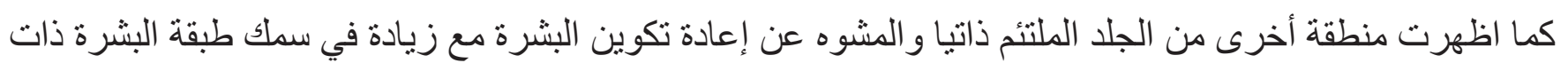

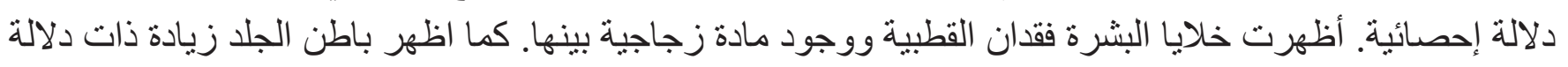

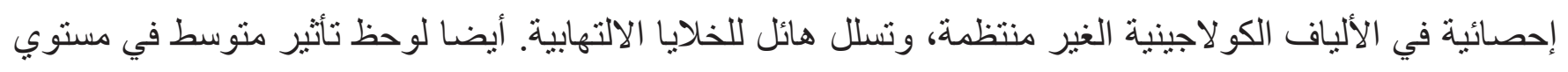

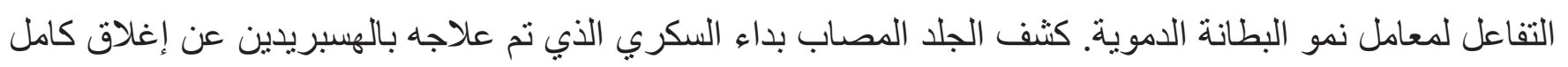

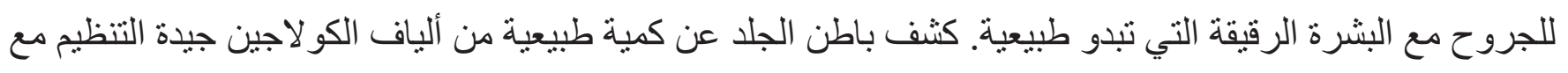

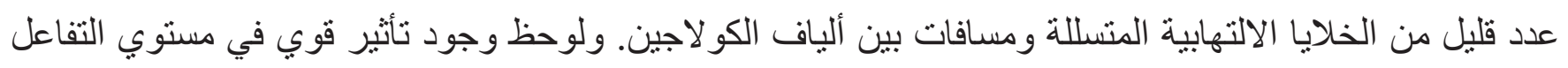
لمعامل نمو البطانة الدموية الذي يعكس تكون أو عية دموية جديدة. الخلاصة: تتعافى تقرحات الجلد في الحيوانات المصابة بالسكري بشكل جزئي وسيئ في وقت طويل نسبيا. بمكن

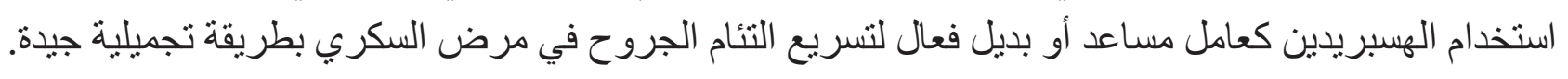

